PERSONALITY AND REPRODUCTIVE SUCCESS IN THE ACHE (PARAGUAY):

IMPLICATIONS FOR THE EVOLUTION OF HUMAN INDIVIDUAL DIFFERENCES

A Dissertation

presented to

the Faculty of the Graduate School

at the University of Missouri-Columbia

In Partial Fulfillment

of the Requirements for the Degree

Doctor of Philosophy

by

DREW H. BAILEY

Dr. David C. Geary, Dissertation Supervisor

July, 2012 
The undersigned, appointed by the dean of the Graduate School, have examined the dissertation entitled

\section{PERSONALITY AND REPRODUCTIVE SUCCESS IN THE ACHE (PARAGUAY): IMPLICATIONS FOR THE EVOLUTION OF HUMAN INDIVIDUAL DIFFERENCES}

presented by Drew H. Bailey, a candidate for the degree of doctor of philosophy, and hereby certify that, in their opinion, it is worthy of acceptance.

\begin{tabular}{|c|}
\hline Professor David C. Geary \\
\hline Professor Amanda Rose \\
\hline Professor Phillip Wood \\
\hline Professor Mark Flinn \\
\hline Professor Craig Palmer \\
\hline
\end{tabular}




\section{ACKNOWLEDGEMENTS}

I thank my collaborators on this project, Robert Walker, Gregory Blomquist, David Geary, and Kim Hill, and my dissertation committee, David Geary, Amanda Rose, Phillip Wood, Mark Flinn, and Craig Palmer, for improving the project and manuscript significantly throughout the process, and for their support during my graduate work.

I also thank the individuals in the Ache communities who participated in the study and those who assisted us in the field, specifically Ricardo Mbekrorogi, Germino Chachugi, and Nemecio Urugi, and thank Keity and Robert Walker for their assistance in the field.

For their assistance with translation and adapting surveys, I thank Elizabeth Bailey, Wilmer Fernandez, Kiero Guerra, Marcia Kearns, and Jon Thacker.

I thank David Geary for his mentoring during my time at Missouri, and for his support during this long and difficult project. I also acknowledge Norm Li and Dev Singh, whose generosity and support inspired me to pursue psychology as a research career. Because of these three individuals, I will always remain dedicated to mentorship.

Finally, I thank my wife, Liz, my family, and my friends for their support during my time in graduate school. They are responsible in great part for all of my accomplishments, and I will always remain grateful for their support. 


\section{TABLE OF CONTENTS}

$\begin{array}{ll}\text { Acknowledgements } & \text { ii }\end{array}$

List of Tables $\quad$ iv

List of Figures $\quad$ V

Abstract vi vi

Introduction 1

Materials and Methods $\quad 11$

$\begin{array}{ll}\text { Results } & 20\end{array}$

$\begin{array}{ll}\text { Discussion } & 27\end{array}$

Appendix 1: Regression Tables for Phenotypic Analyses 33

Appendix 2: Regression Tables for Phenotypic Analyses 35

$\begin{array}{ll}\text { References } & 44\end{array}$

$\begin{array}{ll}\text { Vita } & 52\end{array}$ 


\section{List of Tables}

Table

Page

1. Levels of causation of human individual differences

2. Descriptions and Predictions by Hypothesis and Actual Findings for Current Study

3. Items Used to Calculate Factor Scores, with English Translations

4. Phenotypic Results by Variable

5. Phenotypic Analyses: Models controlling for sex and age

6. Phenotypic Analyses: Moderation Models

7. Breeding Value Analyses: Alive individuals, controlling for sex

8. Breeding Value Analyses: Alive individuals, personality*sex

9. Breeding Value Analyses: Alive individuals, personality*historical period

10. Breeding Value Analyses: Deceased individuals, controlling for sex

11. Breeding Value Analyses: Deceased individuals, personality*sex

12. Breeding Value Analyses: Deceased individuals, personality*historical period 40

13. Age of Death Analyses: Deceased individuals, controlling for sex

14. Age of Death Analyses: Deceased individuals, personality*sex 


\section{List of Figures}

Figure

Page

1. Lowess Function of Reproductive Success by Age 12

2. Assortative Mating Scatterplots 22

3. Extraversion and Male RS. 23

4. Distributions of Reproductive Success for Living and Dead Individuals 24 


\begin{abstract}
This study tested alternative evolutionary mechanisms regarding the maintenance of heritable variation in human personality by examining the relations between personality and reproductive success (RS) in two villages in a traditional natural-fertility population, the Ache of eastern Paraguay. The relation between RS and personality was assessed in each village, and a deep pedigree allowed for an analysis that tested the relation between personality breeding values and RS in deceased ancestors living in the pre-contact forest period. Phenotypic analyses did not indicate significant relations between personality and RS. However, genetically informed analyses indicated that the relation between personality breeding values (specifically agreeableness and conscientiousness) and RS varies with historical period, consistent with the hypothesis of temporal variation in selection pressures. Personality heritability estimates were similar to those estimated in most Western samples. Finally, significant assortative mating for personality was observed, which could contribute to the maintenance of heritable variation in personality.
\end{abstract}




\section{Introduction}

This study tested alternative evolutionary mechanisms regarding the maintenance of heritable variation in human personality (Gangestad, 2010) by examining the relations between personality and reproductive success (RS) in two villages from a traditional natural-fertility population, the Ache of eastern Paraguay (Hill \& Hurtado, 1996). The relation between RS and personality was assessed in the current sample and in an extensive pedigree, which allowed for a genetically informed analysis, including the estimation of the relation between personality breeding values and RS in deceased kin of the current samples. The latter addressed a potential methodological issue with previous research: by ignoring deceased individuals, estimates of trait effects on RS are subject to bias when the trait of interest increases both reproductive opportunity and the risk of early mortality (Symons, 1990).

Humans differ from one another for many reasons, including differences in their immediate proximate environments, their developmental environments, their genes, or some combination (Table 1). The current study addresses the potential evolutionary mechanisms maintaining genetic variation in human personality by measuring relations between personality and reproductive success in a traditional population. Below, I review the hypothesized causes of human individual differences. Then I describe the current study and how it tests different hypotheses of genetic variation in personality. 
Table 1: Levels of causation of human individual differences

\begin{tabular}{|l|l|}
\hline Level & Description \\
\hline $\begin{array}{l}\text { 1. Immediate } \\
\text { Proximate }\end{array}$ & $\begin{array}{l}\text { Events that cause individuals to act differently in the } \\
\text { immediate context }\end{array}$ \\
\hline $\begin{array}{l}\text { 2. Developmental/ } \\
\text { Ontogenetic }\end{array}$ & $\begin{array}{l}\text { Events that affect an individual's development in ways that } \\
\text { affect the phenotype beyond the immediate developmental } \\
\text { context }\end{array}$ \\
\hline $\begin{array}{l}\text { 3. Within species } \\
\text { genetic variation }\end{array}$ & $\begin{array}{l}\text { Individuals vary on genes or alleles that cause phenotypic } \\
\text { differences via (1.) and (2.) }\end{array}$ \\
\hline
\end{tabular}

The immediate proximate level encompasses environment dependent strategies that result in temporary, situation dependent differences among individuals. The developmental level encompasses species-typical reactions to early experiences that result in permanent differences among individuals (e.g., Rodd, Reznick, \& Skolowski, 1997). Of course, if a trait is heritable, the relation between genotype and phenotype must be mediated by some combination of ontogeny (e.g., Yeo, Gangestad, Edgar, \& Thoma, 1999) and immediate proximate causes (e.g., Kendler \& Karkowski-Shuman, 1997). In other words, if variation in genes causes variation in some trait, ontogenetic and immediate environmental differences must be intermediate causes of this variation. However, the converse of this statement is not necessarily true: that is, given that variation in ontogenetic or immediate environmental differences cause variation in some trait, genetic variation does not necessarily also underlie the trait's variation. This is because if two individuals have the same genes, ontogeny and environment can influence patterns of gene expression or epigenetics. 
The ontogenetic and genetic explanations of human individual differences are contrasted below because the former does not necessarily assume individual differences in genotype, whereas the latter does. Also, to say that a trait's variance is not associated with individual differences in genotype, ontogeny, or proximate causes does not imply that this level of causation cannot, or even that it does not affect the trait. Rather, a lack of a trait-cause covariance simply means that it cannot account for individual differences on that trait, even if it does influence trait expression in all individuals.

Evolutionary psychologists have studied the immediate proximate level of causation in the greatest detail. Pawlowski, Atwal, and Dunbar (2008) found that when women are present at a busy intersection, men are more likely to cross the street at a riskier time than when women are not present, consistent with the prediction that risky behavior is often a social display. At the ontogenetic level, the family environment of girls' families may contribute to their later reproductive behavior. Conflict within the family and father absence are associated with an increased likelihood of early pubertal timing and younger age of first child birth (Belsky, Steinberg, \& Draper, 1991; Byrd-Craven, Geary, Vigil, \& Hoard 2007; Draper \& Harpending, 1982; Ellis \& Essex, 2007; Ellis et al., 2003).

However, evolutionary psychologists have not given as much empirical attention to the potential genetic influences on individual differences in traits that are of evolutionary significance (Buss, 2009; Confer et al., 2010). For example, a significant proportion of the variance in the life history traits associated with father absence is due to individual differences at the genetic level (Mendle et al., 2009; Rowe, 2002), though genetically informed analyses suggest that some of 
the variance in father absence is associated with developmental experiences as well (Tither \& Ellis, 2008). This was demonstrated by Tither's and Ellis's finding that when a family was disrupted, pre-menarcheal daughters reached puberty earlier than their older sisters. This effect was not found in families that were not disrupted.

Quantitative geneticists have demonstrated genetic contributions to individual differences in a wide array of human traits, ranging from maximal aerobic capacity (Bouchard et al., 1986) to attitudes (Olson, Vernon, Harris, \& Jang, 2001). From an evolutionary perspective, individual differences attributable to genetic variation are expected for multiple reasons, including the large number of genes needed to construct and maintain the human brain, making it a giant mutational target (Keller \& Miller, 2006; Prokosch et al., 2005), and sexual reproduction, which maintains variance by reshuffling genes each generation (Hamilton \& Zuk, 1982, Williams, 1975). Furthermore, human cultural diversity may contribute to the maintenance of genetic variation because selection pressures may differ in different social ecologies and across time in the same ecology (Chiao \& Blizinsky, 2010; Geary, 2010). Indeed, humans show genetic diversity across cultures (Li et al., 2008).

\section{Personality.}

Decades of research in Western cultures suggest personality varies along five dimensions: extraversion (high sociability, risk taking), agreeableness (socially cooperative, pleasant), conscientiousness (socially reliable, organized), neuroticism (emotionally unstable), and openness to experience (intellectual curiosity) (McCrae \& John, 1992). It has been well documented that individual differences on these personality dimensions are heritable (between 
$30 \%$ and $70 \%$; (Bouchard \& Loehlin, 2001), and potentially related to evolutionarily relevant outcomes, such as number of lifetime sex partners (e.g.,(Nettle, 2005). However, conclusions based on these studies are limited by reliance on modern, low fertility populations. Alvergne et al.'s (Alvergne, Jokela, \& Lummaa, 2010) study of personality and RS in a Senegalese population is a notable exception. Men who were above average in extraversion attainted higher social status, were more likely to marry polygynously, and had more children than their more introverted peers. The results are consistent with positive selection for extraversion in men in this population, but overall there is little consensus as to the evolutionary mechanisms that maintain heritable variation in human personality (Gangestad, 2010).

The candidate mechanisms include (i) selective neutrality, (ii) polygenic mutation-selection balance, (iii) balancing selection (including spatial-temporal variation, heterozygote advantage or epistasis), (iv) antagonistic pleiotropy, and (v) frequency-dependent selection (Keller \& Miller, 2006). Table 2 shows the pattern of results that would be consistent with each of these mechanisms. For instance, polygenic mutation-selection balance predicts main effects of personality on RS and assortative mating, but not necessarily interactions for this trait with sex or the other dimensions of personality. Spatial-temporal variation, in contrast, predicts different relations between personality and RS across villages and historical periods but not necessarily interactions between sex and personality or among different dimensions of personality.

Selective neutrality can maintain genetic variation when population size is high and selection is weak (Lynch \& Hill, 1986; Penke, Denissen, \& Miller, 2007) such that individual differences in personality are not related to survival or reproduction. However, selective neutrality is an 
Table 2: Descriptions and Predictions by Hypothesis and Actual Findings for Current Study

\begin{tabular}{|c|c|c|c|c|c|c|c|}
\hline & Description & $\begin{array}{l}\text { Relevant } \\
\text { citations }\end{array}$ & $\begin{array}{l}\text { Effect of } \\
\text { personality }\end{array}$ & $\begin{array}{l}\text { Interactions among } \\
\text { personality traits } \\
\text { or nonlinear } \\
\text { relations }\end{array}$ & $\begin{array}{l}\text { Personality } \\
\text { by hist. } \\
\text { period } \\
\text { interactions }\end{array}$ & $\begin{array}{l}\text { Personality } \\
\text { by sex } \\
\text { interaction }\end{array}$ & $\begin{array}{l}\text { Assortative } \\
\text { mating }\end{array}$ \\
\hline $\begin{array}{l}\text { Selective } \\
\text { Neutrality }\end{array}$ & $\begin{array}{l}\text { Phenotypic variation and associated } \\
\text { mutations do not affect fitness }\end{array}$ & $\begin{array}{l}\text { (Lynch \& } \\
\text { Hill, } \\
\text { 1986; } \\
\text { Penke, et } \\
\text { al., 2007) }\end{array}$ & No & $\mathrm{No}$ & No & No & No \\
\hline $\begin{array}{l}\text { Polygenic } \\
\text { Mutation- }\end{array}$ & $\begin{array}{l}\text { Many mutations with small negative } \\
\text { effects on fitness accumulate to } \\
\text { create heritable maladaptive } \\
\text { variation in otherwise adaptive } \\
\text { phenotypes }\end{array}$ & $\begin{array}{l}\text { (Alvergne, } \\
\text { et al., } \\
\text { 2010; D. } \\
\text { M. Buss, } \\
\text { 2006; } \\
\text { Keller \& } \\
\text { Miller, } \\
\text { 2006) }\end{array}$ & Yes & No & No & No & Yes \\
\hline $\begin{array}{l}\text { Spatial/ } \\
\text { Temporal } \\
\text { Variation }\end{array}$ & $\begin{array}{l}\text { Selection pressures change across } \\
\text { time and place }\end{array}$ & $\begin{array}{l}\text { (Dingema } \\
\text { nse, et al., } \\
2004)\end{array}$ & Maybe & No & Yes & No & No \\
\hline $\begin{array}{l}\text { Heterozygote } \\
\text { Advantage or } \\
\text { Epistasis }\end{array}$ & $\begin{array}{l}\text { The most adaptive genotype is } \\
\text { heterozygous, or genes interact to } \\
\text { affect fitness }\end{array}$ & $\begin{array}{l}\text { (Allison, } \\
\text { 1954; } \\
\text { Eaves, et } \\
\text { al., 1990) }\end{array}$ & Maybe & Yes & No & No & No \\
\hline $\begin{array}{l}\text { Sexually } \\
\text { Antagonistic } \\
\text { Pleiotropy } \\
\end{array}$ & $\begin{array}{l}\text { One allele or combination of alleles } \\
\text { has opposite effects on the fitness of } \\
\text { males and females }\end{array}$ & $\begin{array}{l}\text { (Penke, } \\
\text { 2010) }\end{array}$ & Maybe & No & No & Yes & No \\
\hline $\begin{array}{l}\text { Frequency- } \\
\text { Dependent } \\
\text { Selection }\end{array}$ & $\begin{array}{l}\text { Relation between a genotype and } \\
\text { fitness is moderated by the levels of } \\
\text { that genotype in the population }\end{array}$ & $\begin{array}{l}\text { (Mealey, } \\
\text { 1995; D. } \\
\text { S. Wilson, } \\
\text { 1994) }\end{array}$ & Maybe & No & Maybe & No & No \\
\hline
\end{tabular}




\begin{tabular}{|l|l|l|c|c|c|c|c|}
\hline $\begin{array}{l}\text { Assortative } \\
\text { Mating }\end{array}$ & $\begin{array}{l}\text { Males and females are similar on } \\
\text { alleles for a trait }\end{array}$ & $\begin{array}{l}\text { (Zietsch, } \\
\text { et al., } \\
\text { 2011) }\end{array}$ & No & No & No & No & Yes \\
\hline $\begin{array}{l}\text { Observed } \\
\begin{array}{l}\text { Personality } \\
\text { Results }\end{array}\end{array}$ & (findings from current study) & & Maybe & Maybe & N/A & No & Yes \\
\hline B.V. Results & (findings from current study) & & Yes & N/A & Yes & Yes \\
\hline
\end{tabular}

*Yes: $p<0.05$; Maybe: $p<0.10 \mathrm{NP}=$ no prediction

\footnotetext{
${ }^{1}$ Breeding value analyses did not assess assortative mating, personality X personality interactions, or nonlinear relations with personality, because it is impossible to determine whether these results (many of which were highly statistically significant) reflected reality or were artifacts of the method used to estimate ancestral breeding values. An assumption of this method is that variance increases over time. Because of this, assortative mating estimates may be biased positively, because individuals living in the forest period are much more similar to each other on personality than to others in the sample. Also, personality*personality interaction and quadratic personality terms have higher values of personality as a function of time, and because of heteroskedasticity, simply controlling for time does not solve this problem.
} 
unlikely mechanism because number of lifetime sex partners and lifetime RS is related to personality in nonhuman species (Smith \& Blumstein, 2008) and in some cultures (Eaves, Martin, Heath, Hewitt, \& Neale, 1990; Nettle, 2005; Penke, et al., 2007), as is longevity, relationship satisfaction, criminality, psychopathology, job performance, and other potentially reproductively relevant behaviors that are correlated with personality (for review, see (Ozer \& Benet-Martinez, 2006).

Polygenic mutation-selection balance occurs when many mutations with small negative effects on fitness accumulate to create maladaptive heritable variation in phenotypes that are otherwise adaptive. It appears that mutation-selection balance may contribute to variation in several domains that could affect reproductive prospects, including risk for schizophrenia, autism, and cognitive disability (Keller \& Miller, 2006; Yeo et al., 2011). The same maybe true for neuroticism and extraversion (D. M. Buss, 2006), as emotionally stable individuals are universally preferred as long-term mates (D. M. Buss \& Barnes, 1986; D. M. Buss, et al, 1990), and unstable individuals and highly introverted individuals are at increased risk for some pathological conditions (e.g., schizophrenia in men) associated with lower RS (Ozer \& BenetMartinez, 2006; Trull \& Sher, 1994; van Os \& Jones, 2001). Further, consistent with this hypothesis, personality traits are polygenic and show non-additive genetic variation (Eaves et al., 1998; Martin et al., 1988; Keller et al., 2005), consistent with the hypothesis that selection for or against any particular allele would be weak.

Four classes of balancing selection have been proposed as potential evolutionary-genetic explanations of common, heritable variation in human personality and psychological functioning 
(Keller \& Miller, 2006): Spatial and temporal variation, heterozygote advantage, antagonistic pleiotropy, and frequency-dependent selection. Spatial and temporal variation occurs when selection pressures change across time and place such that no single phenotype has a consistent reproductive advantage (e.g., (Dingemanse, Both, Drent, \& Tinbergen, 2004)). Selection can maintain genetic variation in traits for which a heterozygous phenotype is the most adaptive, and a few examples have been demonstrated (e.g., sickle-cell anemia; (Allison, 1954)), perhaps because selection eventually generates a solution to the problem of maladaptive homozygous phenotypes (Keller \& Miller, 2006). Epistasis occurs when genes moderate each others' effects. At the phenotypic level, Eaves et al. (Eaves, et al., 1990) found that in postmenopausal women neuroticism and extraversion interacted to predict lifetime RS. The combinations of high neuroticism and low extraversion and high extraversion and low neuroticism were associated with the highest RS, whereas the combination of high extraversion and high neuroticism and low neuroticism and low extraversion were associated with the lowest. One result is maintenance of variation in both neuroticism and extraversion in women.

Antagonistic pleiotropy occurs when an allele affects multiple traits, and the effect on one or more of those traits is negatively related to fitness and positively related to fitness on one or more other traits (Williams, 1957). The current study tests specifically for sexually antagonistic pleiotropy, which occurs when a trait has opposite effects on the fitness of males and females. Penke (Penke, 2010) proposed that variation in antisocial personality traits which are more positively related to male than female RS (Jonason, Li, Webster, \& Schmitt, 2009) could be maintained in this way. Indeed, antisocial men who tend to be low on anxiety and high on 
extraversion tend to have many sexual partners, but as noted, Eaves et al. (Eaves, et al., 1990) found that a similar combination of traits was related to lower RS success in women.

Frequency-dependent selection occurs when the relation between a heritable phenotype and fitness is moderated by frequency of that phenotype in the population. Wilson (D. S. Wilson, 1994) hypothesized that frequency-dependent selection would act on trait specialization, such that individuals able to adopt a social niche would exist at some equilibrium with individuals that could migrate between niches. Mealey (Mealey, 1995) proposed a version of this hypothesis with respect to antisocial behavior (e.g., high extraversion, low conscientiousness) which may be a frequency-dependent strategy maintained at a low frequency in the population.

Assortative mating is another potential mechanism that maintains variation in human personality. If either selective neutrality or balancing selection contributes to variation in a trait, assortative mating for that trait can help maintain variance by carving out reproductive niches for individuals at all levels of the phenotype. For example, an individual high on openness to experience will be preferred as a mate by other open individuals, and an individual low on openness to experience will be preferred as a mate by other individuals low on openness.

Evidence suggests that humans mate assortatively, albeit weakly (correlation coefficients between couples in a large sample ranged from 0.04 to 0.16 ; (Zietsch, Verweij, Heath, \& Martin, 2011)) on several personality traits. Alvergne and colleagues (Alvergne, et al., 2010) reported a correlation coefficient between couples of .39 on extraversion in a high fertility population. Assortative mating for that trait can help maintain genetic variance in the trait by carving out 
reproductive niches for individuals displaying all levels of the phenotype. However, reproductive decisions in humans, especially in traditional societies, are often not simply autonomous choices made by individuals but are regulated and controlled by parents and other kin (Apostolou, 2007; Chagnon, 1979; Radcliffe-Brown, 1927), so the extent to which the assortative mating hypothesis is a plausible explanation for the maintenance of heritable variation in human individual differences is unclear.

\section{Materials and Methods}

Participants. The Ache are indigenous to eastern Paraguay and until the 1970s were full-time hunter-gatherers (Hill \& Hurtado, 1996). Some now live on a reservation near the Mbaracayu Natural Reserve, although many of them still make excursions into the forest, during which men spend about seven hours per day hunting (Hill \& Hawkes, 1983) and women spend six hours per day on work activities such as moving camp and harvesting and processing food (Hurtado, Hawkes, Hill, \& Kaplan, 1985). Data were collected in two Ache communities: Kuetuvy (KT) and Arroyo Bandera (AB). When in their communities, individuals spend time working in agricultural fields, on household tasks, and on watching or participating in soccer and volleyball games.

The communities differ in organization. In KT, homes are arranged in a circle with a common central area, whereas $\mathrm{AB}$ has a common central area but homes are more dispersed. KT was recently founded (2001) by a self-selected group of individuals who moved closer to the forest to live a more traditional lifestyle and tend to be more community-oriented than individuals living in $\mathrm{AB}$, a community that has trended more towards individual nuclear families with larger 
distances amongst houses. Migration between these villages occurs and some individuals have close relatives living in both villages.

Participants included $77 \mathrm{KT}$ residents $(40$ male, mean age $=33.72, \mathrm{SD}=13.97)$ and $33 \mathrm{AB}$ residents $(18$ male, mean age $=26.97, \mathrm{SD}=10.27)$. Participants had an average of 3.55 children $(\mathrm{SD}=3.49)$. After adjusting for the Lowess function of fitness on age (Figure 1) and sex, the mean number of children did not differ across villages $(t[105]=-0.20, p=0.84$; raw means $=$ 4.03, 2.45 for $\mathrm{KT}$ and $\mathrm{AB}$, respectively).

\section{Lowess Function for Fitness by Age}

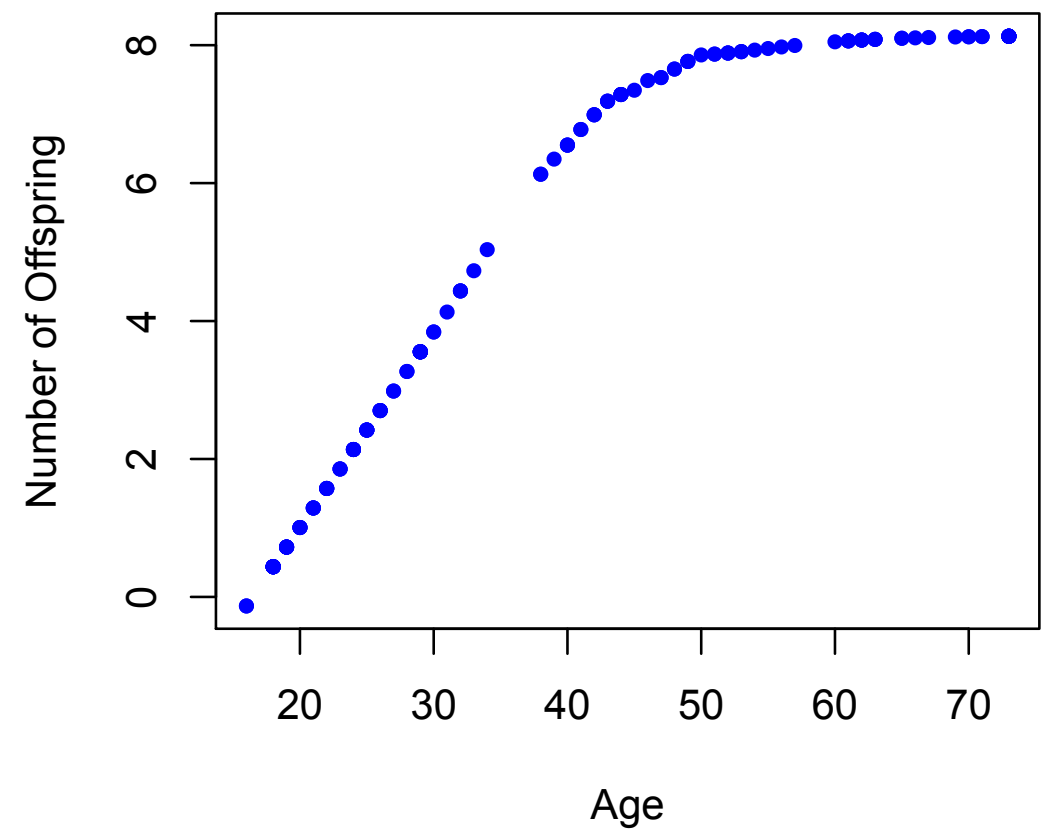

Figure 1: Lowess Function of Reproductive Success by Age.

This Lowess curve (tension $=2 / 3$ ) is a more flexible way to account for nonlinear variation than including quadratic components in regression analyses; however, the interpretation of results below did not differ if quadratic components rather than the Lowess values were used as controls. 
Heritability analyses include a sample of 2,132 people in a pedigree derived from a detailed genealogy (Hill \& Hurtado, 1996), 1,253 of whom were 15 or older with personality breeding values that could be estimated. Individuals born in 1940 or before are designated as the "forest" group ( $n=369,59 \%$ male), as they began to reproduce before the 1970s, which Hill and Hurtado designate as the "contact period." Individuals in the "forest" group focused on the search for food (Hill \& Hurtado, 1996), and men provided the majority of calories, primarily from meat (Hill, Hawkes, Hurtado, \& Kaplan, 1984). Hill and Hurtado described them as "the most competent forest people we have ever seen, and the most generous in sharing their food with each other in a band-level context. Their hunting and tracking skills and arboreal agility far surpass those of any other lowland South American population we have observed (p. 78)." During this period, individuals travelled in bands characterized by flexible membership and ranging from 3 to 160 individuals in size (Hill \& Hurtado, 1989). Approximately every two or three years, up to 400 Ache individuals would gather in the forest and clear out a large space, in which the adult males would engage in a long, violent, and turbulent club fight (Hill \& Hurtado, 1996).

Individuals born between 1941 and 1960 are designated as the "contact" group $(n=272,55 \%$ male) for this study. From 1971 to the end of 1977, most Ache bands made first peaceful contacts (p. 100,(Hill \& Hurtado, 1996)) with non-Ache Paraguayans and Westerners. This led to changes in social structure: Young Ache men who became the most quickly accustomed to life outside the forest by learning Spanish and non-Ache Paraguayan customs gained status and sometimes gained the wives of the older men who did not adapt as quickly. Also, virgin soil 
epidemics (i.e., epidemics resulting from a people's first exposure to a new disease) killed approximately $40 \%$ of the Ache individuals during this time (Hill \& Hurtado, 1996).

Individuals born after 1960 are designated as the "reservation" group ( $n=608,53 \%$ male), as they lived on reservations after the tumultuous contact period for the majority of their reproductive years. Between 1980 and the present, the Ache have mainly decreased the amount of time they spend in the forest and instead practice subsistence horticulture, growing manioc, which constitutes the majority of their diets (Hill \& Hurtado, 1996). Some men also participate in wage labor, but in 1992, the average Ache nuclear family's net worth was approximately $\$ 12$ (Hill \& Hurtado, 1996). The Ache primarily practice a flexible residence pattern with frequent spouse switching among young individuals, as before the reservation period, but do not participate in many of the ceremonies traditional to the Ache during the forest period, and no longer participate in club fights. Hill and Hurtado (Hill \& Hurtado, 1996) describe Ache "social and political life" as "in a state of transition ... with missionary and Paraguayan peasant influence increasing over time (p. 79)."

Measures. The commonly used Big Five survey was used to assess personality (McCrae \& John, 1992). I used a 44-item Spanish version developed and validated by Benet-Martínez and John (Benet-Martinez \& John, 1998) in samples of native Spanish speakers and bilingual (English and Spanish) speakers. An Ache individual living in KT was able to translate 43 of the 44 personality items. Participants' RS and genetic relatedness were determined from the pedigree. To capture individual differences beyond that associated with age-typical number of offspring, RS was 
operationalized as the difference between participant's actual number of offspring and their number of offspring predicted by the Lowess function of fitness on age.

Procedure. Individuals in both villages were informed about the study by the visiting investigators, an Ache research assistant, or by word of mouth. The testing area was a large room in a village building. The Ache translator of the personality items administered the survey to participants in groups of 2 to 11. Participants sat around a table while the interviewer described the 5-point scale used to answer each item [ranging from "describes me very well" (5) to "does not describe me at all" (1)]. Then the interviewer read each question once in Ache and once in Spanish. Participants wrote their responses on the 5 point scale onto a sheet of paper with spaces designated for each item's answer. Thirteen individuals in KT were unable to write and thus were assessed individually by the interviewer who recorded the responses. A separate interviewer conducted the survey in $\mathrm{AB}$, where participants sat at desks in a school classroom. The interviewer used the same methods as the interviewer in KT. All participants in both villages were compensated 20,000 Guarans (approximately \$4.50).

Construct Validity. A confirmatory factor analysis (CFA) was run on the 43 items to determine if the same five factor model fitted to Western samples provided an acceptable fit in this population. Preliminary analyses and inspection of the surveys indicated that many participants were not using the entire 5-point scale (i.e., some participants used only 1, 2, and 3, whereas others used 3, 4, and 5). To control for this, the first model included a method factor on which every item loaded and was constrained to be equivalent to all other loadings. For model 
identification, the highest loading item from each non-method factor was set to 1 (or -1, in the case of negatively loading items).

This model was highly significant $\left(\chi^{2}[849]=1775.03, p<.00005\right)$, indicating the five factor model was a poor fit. Other model indices also indicate poor fit $(\mathrm{RMSEA}=.100, \mathrm{TLI}=.41, \mathrm{CFI}$ $=.45)$. Though not desirable statistically, the RMSEA for this model was within the range of RMSEA values for many personality measures (Hopwood \& Donnellan, 2010); nonetheless, the fit of the model based on the TLI and CFI are substandard (Hopwood \& Donnelan, 2010, reported TLI values ranging from $.52-.70$ and CFI values from $.61-.79$, and CFI values $<.90$ are considered poor model fits). Items and loadings appear in Table 3. 
Table 3. Items Used to Calculate Factor Scores, with English Translations

\begin{tabular}{|c|c|c|c|}
\hline Extraversion & Item & English Translation & Factor Loading \\
\hline 1. & tiende a ser callado (R) & tends to be quiet & -1.00 \\
\hline 2. & $\begin{array}{l}\text { es asertivo, no teme } \\
\text { expresar lo que quiere }\end{array}$ & $\begin{array}{l}\text { is assertive, not afraid to } \\
\text { express what one wants }\end{array}$ & .58 \\
\hline \multicolumn{4}{|l|}{ Agreeableness } \\
\hline 1. & tiende a ser criticón (R) & tends to be critical & -.64 \\
\hline 2. & $\begin{array}{l}\text { es considerado y amable } \\
\text { con casi todo el mundo }\end{array}$ & $\begin{array}{l}\text { is considerate and kind } \\
\text { to almost everyone }\end{array}$ & 1.0 \\
\hline 3. & $\begin{array}{l}\text { es indulgente, no le } \\
\text { cuesta perdonar }\end{array}$ & is forgiving & .52 \\
\hline \multicolumn{4}{|c|}{ Conscientiousness } \\
\hline 1. & $\begin{array}{l}\text { hace planes y los sigue } \\
\text { cuidadosamente }\end{array}$ & $\begin{array}{l}\text { makes plans and follows } \\
\text { them carefully }\end{array}$ & 1.0 \\
\hline \multicolumn{4}{|l|}{ Neuroticism } \\
\hline 1. & $\begin{array}{l}\text { se preocupa mucho por } \\
\text { las cosas }\end{array}$ & $\begin{array}{l}\text { is very concerned about } \\
\text { things }\end{array}$ & 1.0 \\
\hline \multicolumn{4}{|l|}{ Openness } \\
\hline 1. & $\begin{array}{l}\text { es original, se le ocurren } \\
\text { ideas nuevas }\end{array}$ & $\begin{array}{l}\text { is original, comes up } \\
\text { with new ideas }\end{array}$ & .60 \\
\hline 2. & $\begin{array}{l}\text { tiene intereses muy } \\
\text { diversos }\end{array}$ & $\begin{array}{l}\text { has many diverse } \\
\text { interests }\end{array}$ & .44 \\
\hline 3. & es inventivo & is inventive & .50 \\
\hline 4. & es ingenioso, analítico & is clever, analytic & .83 \\
\hline 5. & $\begin{array}{l}\text { le gusta reflexionar, jugar } \\
\text { con las ideas }\end{array}$ & $\begin{array}{l}\text { likes to reflect, play } \\
\text { with ideas }\end{array}$ & 1.0 \\
\hline 6. & $\begin{array}{l}\text { es educado en arte, } \\
\text { música, o literatura }\end{array}$ & $\begin{array}{l}\text { is educated in art, } \\
\text { music, or literature }\end{array}$ & .47 \\
\hline
\end{tabular}


To test if model fit was due to poor item translation or because the five factor model is less appropriate for describing Ache individuals than individuals from Western cultures, Kim Hill, an anthropologist with over 30 years of experience working in these and other Ache communities, rated 66 Ache men on all of the survey items that had confirmatory factor analysis loadings greater than 0.4. Others' reports of personality traits are underutilized and perhaps more useful in some ways than self-reports and on average yield agreement between self-reports and other reports in the range of .39 to .51 for friends and from .18 to .32 for work colleagues (Connelly \& Ones, 2010). Thirty-one of the men rated by Kim Hill had been administered the 43 personality items, and the remaining 35 were new. The combination of the administered items (i.e., selfreport) and those provided by Kim Hill increased the sample with at least self-reported or otherreported personality data to 145 individuals. Because in the original confirmatory factor analysis, three factors (extraversion, conscientiousness, and neuroticism) yielded fewer than the 3 highloading items required per factor for identification purposes, the model with both sets of ratings was not tested with a CFA.

When the self-report items loaded greater than .4 and corresponding other-report items were standardized $(M=0, S D=1)$ and summed to create factor scores, only conscientiousness and openness to experience $(0.45,0.43 ; p \mathrm{~s}=0.01,0.02$, respectively) were significantly correlated between raters ${ }^{2}$. Conscientiousness and openness to experience values for all 145 individuals were defined as the sum of each participant's self- and other-report $z$-scores for each factor; data that were missing for either self $(\mathrm{n}=35)$ or other $(\mathrm{n}=72)$ report scores (but not both) were

${ }^{2} r$ s for extraversion, agreeableness, and neuroticism $=0.00,0.03,-0.07$, respectively; all $p>$ 0.70. Agreements for ratings of conscientiousness and openness to experience were at the high ends of what Connelly and Ones (34) observed in a meta-analysis of correlations between selfand other-reports of personality data. 
estimated as the average of 5 iterations of Multiple Imputation in IBM SPSS Statistics ver. 19.0. Extraversion, agreeableness, and neuroticism were defined only as the other-reports of these variables; individuals with only self-report data were not included in analyses involving these factors $(n=79)$.

In all, the personality variables used to test evolutionary models were conscientiousness, openness to experience (the sums of self- and other-reports, $n=145$ ), extraversion, agreeableness, and neuroticism (other-reports of men only, $n=66$ ).

Statistical Analyses. First, I regressed RS on personality. I then separately investigated the moderating effects of sex and the other personality variables by separately adding their interactions to the initial model. Assortative mating was assessed by calculating correlations between spouses.

I calculated heritability and breeding values for personality dimensions with their associated standard errors using a restricted maximum-likelihood animal model (Kruuk, 2004; A. J. Wilson et al., 2010). The animal model is a mixed model, and the random effects are variance components that estimate the proportion of the variance in a trait attributable to additive genetic variance and to other factors. In this case, the only fixed effect was the population mean of personality. A breeding value is the effect of an individual's genes on a particular trait. The same random effects (breeding value and residual) were used for all five personality variables. The covariance matrix for the breeding values was assumed to be $\mathbf{A}$ (the additive genetic relationship matrix) with elements $2 \theta_{\mathrm{ij}} \mathrm{V}_{\mathrm{A}}$ with kinship coefficients (for individuals $\mathrm{i}$ and $\mathrm{j}$ as $\theta_{\mathrm{ij}}$ ) calculated 
from an Ache pedigree of 2,132 people, and $\mathrm{V}_{\mathrm{A}}$ as the additive genetic variance of the trait. Residuals were assumed to be uncorrelated $\left(\mathrm{IV}_{\mathrm{R}}\right)$. All quantitative genetic models were run in ASREML3 (Gilmour, Gogel, Cullis, \& Thompson, 2009). Advantages of the animal model include no assumptions associated with assortative mating or inbreeding (Kruuk, 2004).

However, the current study lacked a measure of common environment, which would lead to the overestimation of the heritability of personality traits (Kruuk, 2004), assuming that common environment contributes to personality. On the basis of studies in Western populations, common environmental influences have generally shown to be small in studies of personality using twin, family, and adoption designs (Bouchard \& Loehlin, 2001).

RS was regressed on personality breeding values separately for living and deceased individuals. To account for the variation in the precision of breeding value estimates, weighted regression was used, with each observation weighted by one divided by the standard error of the breeding value estimate; thereby weighting breeding values with large standard errors downward. I then separately investigated the moderating effects of sex and time period by separately adding their interactions to the initial models. Then, for deceased individuals, age of death was regressed on personality breeding values, and sex and time period were assessed as potential mediators.

\section{Results}

Personality and RS. Summary results are in Table 2, and in greater detail in Table 4. Agreement between self- and other-report was obtained for conscientiousness and openness to experience, as noted. In models that controlled for age and sex, neither conscientiousness nor openness to experience was related to RS ( $p \mathrm{~s}>.80)$; the interactions of sex with conscientiousness and 
openness to experience were also non-significant $(p s>.10)$. For these variables, no evidence was found for either mutation-selection balance (no correlations with RS) or sexually antagonistic pleiotropy (relation did not differ by sex).

Table 4: Phenotypic Results by Variable

\begin{tabular}{|l|l|l|l|l|}
\hline & \multicolumn{5}{|c|}{ Potential Moderators of the Relation between Personality and } \\
Reproductive Success (RS)
\end{tabular}

Yes: $p<0.05$; Maybe: $p<0.10$

The interaction between conscientiousness and openness to experience, controlling for age and sex, did not correlate with RS $(p=.14)$. There was a trend for a nonlinear relation between conscientiousness and RS, controlling for age, sex, and extraversion $(t[138]=-1.89, p=0.06)$, but no such relation between openness to experience and RS. Individuals with very low or high levels of conscientiousness had slightly lower RS than individuals who were average, providing tentative evidence for heterozygote advantage for conscientiousness. 
There were 33 male and female pairs in the pedigree with non-missing personality data that had reproduced. These couples showed strong assortative mating for both conscientiousness ( $r=0.41$, $p=0.02)$ and openness to experience $(r=0.43, p=0.01)$ (Figure 2$).$
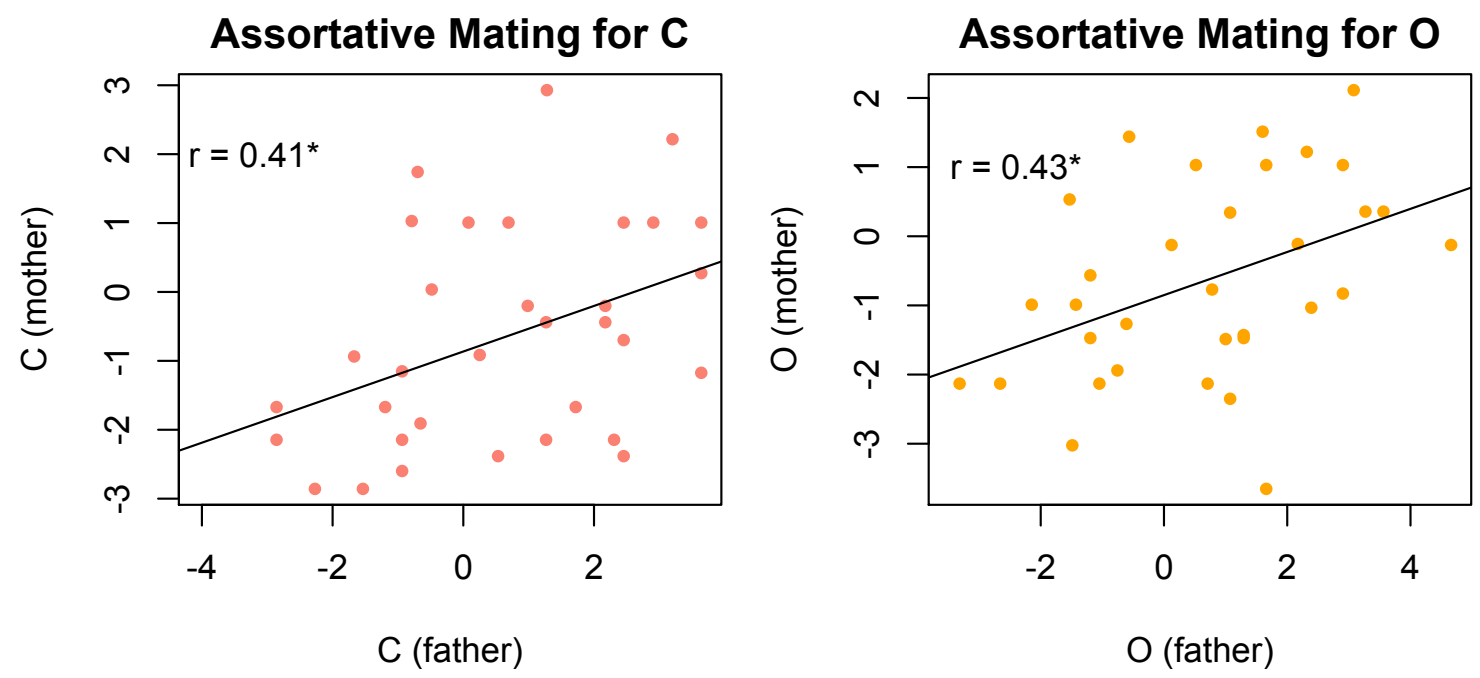

Figure 2: Assortative Mating.

Both of these relations remain significant after controlling for age. Also, after simultaneously removing the two couples in the sample for which both members were interviewed by the research assistant, both relations remained significant.

Other-Report for Male Personality. These data on extraversion, agreeableness and neuroticism included only males (see Methods).

For these males, controlling for age, there was no relation between agreeableness or neuroticism and RS, but a trend for higher extraversion to be associated with higher RS $(t[70]=1.86, p=$ 0.07; Figure 3). Separate models controlling for age, sex, and linear effects of extraversion (model 1), agreeableness (model 2), or neuroticism (model 3) yielded nonsignificant non-linear relations between each of these personality variables and RS (Appendix 1: Table 5). 


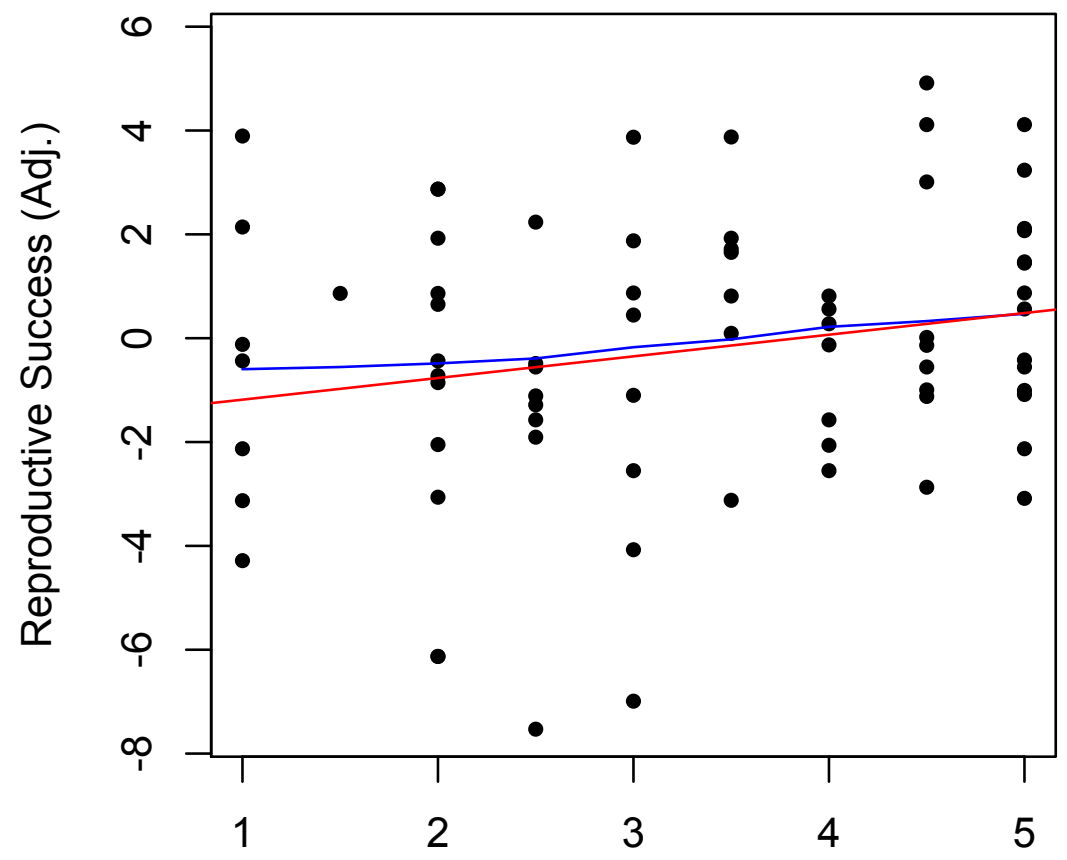

Other Rated Extraversion

Figure 3: Extraversion and Male RS.

The red line is line corresponding to a regression of RS on other rated extraversion; the blue curve is Lowess approximation of the function.

Analyses of Heritability and Breeding Values. Heritability estimates (and standard errors) for the five personality factors were .79 (S.E. $=.28), .66(.31), .26(.17), .57(.36)$, and $.09(.15)$ for extraversion, agreeableness, conscientiousness, neuroticism, and openness, respectively.

Only individuals who survived at least to age 15 were included in the following analyses. Living individuals' RS was calculated from the Lowess function of RS across age for the entire sample of living individuals from Hill's pedigree $(n=768)$. RS was operationalized as the difference between participant's actual number of offspring and their number of offspring predicted by the 
Lowess function of fitness on age. For deceased individuals $(n=485)$, RS was operationalized as the number of offspring that occurred in the pedigree. Because of this method, RS was symmetrically, approximately normally distributed for living individuals but distributed as a Poisson distribution for deceased individuals (histograms included as Figure 4). Furthermore, age of death can be used as a dependent variable for deceased but not living individuals. Therefore, analyses were conducted separately for living and deceased individuals, using regression for living individuals and Poisson regression for deceased individuals.
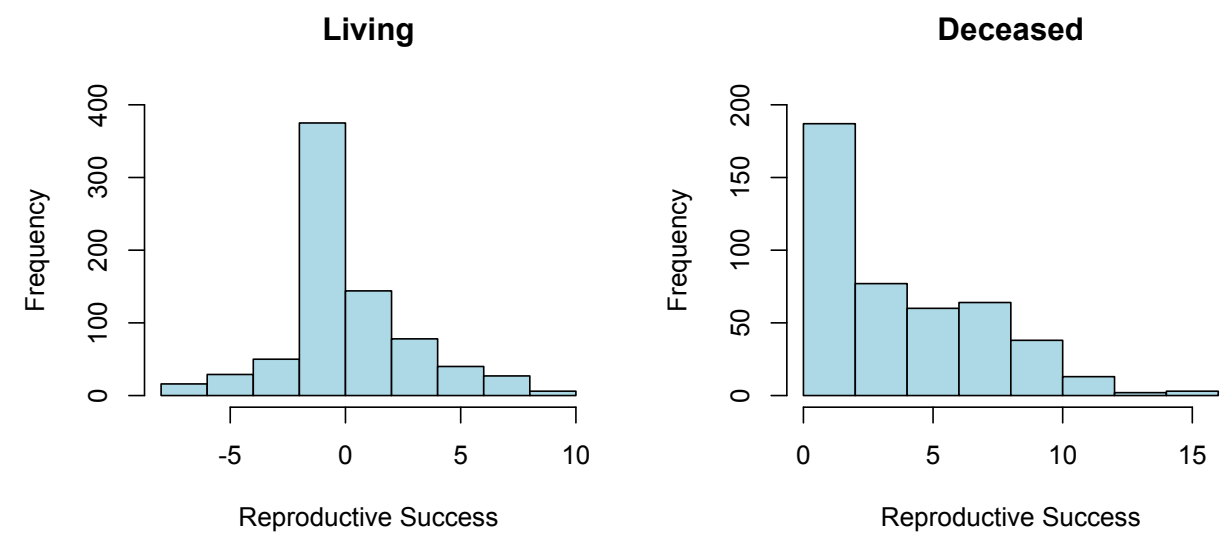

Figure 4. Distributions of Reproductive Success for Living and Dead Individuals

First for living and then for deceased individuals, RS was regressed on personality breeding values and investigated for the moderating effects of sex and time period by separately adding their interactions to the initial models. Results from these models are summarized in the last row of Table 2, and in greater detail in Table 6. 
Table 6: Breeding Value Results by Variable

\begin{tabular}{|l|l|l|l|}
\hline & \multicolumn{3}{|c|}{$\begin{array}{r}\text { Potential Moderators of the Relation } \\
\text { between Personality and Reproductive } \\
\text { Success }\end{array}$} \\
\hline Personality & None & $\begin{array}{l}\text { Historical } \\
\text { Period }\end{array}$ & Sex \\
\hline Extraversion & No, No & No, Yes & No, No \\
\hline Neuroticism & No, Yes & No, Yes & No, No \\
\hline Agreeableness & Yes, Maybe & $\begin{array}{l}\text { Maybe, } \\
\text { Yes }\end{array}$ & No, Yes \\
\hline Conscientiousness & No, No & Yes, Yes & No, No \\
\hline Openness & No, Yes & No, No & Yes, No \\
\hline $\begin{array}{l}\text { Significant } \\
\text { effects/Tests }\end{array}$ & $2 / 10$ & $7 / 20^{*}$ & $2 / 10$ \\
\hline
\end{tabular}

Yes: $p<0.05$; Maybe: $p<0.10$

*There were twice as many tests of statistical significance when assessing historical period as a moderator, because there were two interaction terms for these models.

Living Individuals. Controlling for sex, only breeding values for agreeableness $(b=.645, t[738]$

$=2.38, p=.02$ ) were significantly and positively related to RS. When sex by personality

interactions were added to these models, only the sex by openness to experience interaction was significant $(t[737]=1.99, p=.047)$. For women, higher openness was associated with lower RS $(\mathrm{b}=-2.848, \mathrm{~ns})$ but this relation was less negative and even slightly positive $(-2.848+3.642=$ .794) for men than it is for women (details of these models are provided in Appendix 2: Tables 7-9).

When time period and personality by period were added to the initial models, the interaction between agreeableness and the reservation period contrast was marginally significant $(b=$ $2.138, t[734]=-2.14, p=.052)$, and conscientiousness interacted significantly with the 
reservation historical period contrast $(b=2.706, t[734]=2.71, p=.03)$. In effect, the relation between agreeableness and RS was less positive in the reservation period than in the forest period, and the relation between conscientiousness and RS was significantly less negative in the reservation period than in the forest period. Higher agreeableness was associated with significantly higher RS in the forest relative to the reservation period, whereas lower conscientiousness was associated with significantly higher RS in the forest relative to the reservation period.

Deceased Individuals. Controlling for sex, only breeding values for neuroticism $(b=-.194, z=$ 2.35, $p=.02 ;$ model $\mathrm{df}=481)$ and openness to experience $(\mathrm{b}=-.409, z=-2.25, p=.02 ; \mathrm{df}=$ 481) were significantly related to RS, both negatively. When sex by personality interactions were added to these models, only the agreeableness by sex interaction was significant $(b=-.426, z=$ $3.15, p=.002 ; \mathrm{df}=480)$, indicating that agreeableness was significantly more positively related to RS for women than for men among deceased individuals. This pattern is similar to the pattern identified among living individuals (details of these models are provided in Appendix 2: Tables 10-12).

When period and personality by period were added to the initial models, extraversion interacted significantly with the contact and reservation period contrasts $(b=.462,1.00, z=2.10,1.97, p$ both $<.05 ; \mathrm{df}=477)$, as did agreeableness $(\mathrm{b}=-.373,-1.15, z=-2.01,-3.58, p$ both $<.05 ; \mathrm{df}=$ 477). The pattern indicated that extraversion was more positively, and agreeableness was more negatively associated with RS in the contact and reservation periods than in the forest period. Conscientiousness interacted significantly with the contact period contrast $(\mathrm{b}=.799, z=2.65, p$ 
$=.008 ; \mathrm{df}=477)$; specifically, conscientiousness was more positively associated with RS in the contact period than in the forest period. Finally, neuroticism interacted significantly with the contact period contrast $(\mathrm{b}=.514, z=2.32, p=.02 ; \mathrm{df}=477)$, indicating that neuroticism was significantly less negatively associated with RS in the contact period than in the forest period.

In separate models controlling for sex, breeding values for extraversion, conscientiousness, neuroticism, and openness to experience $(\mathrm{b}=-5.77,-7.35,-7.33,-19.65$; all $t[481]<-2.00$, all $p$ $<.05)$ were all significantly negatively related to age of death, indicating a longer lifespan for individuals low in extraversion, conscientiousness, neuroticism, or openness. No significant personality interactions by sex were observed, but extraversion interacted with the contact period contrast $(\mathrm{b}=10.14, t[477]=2.14, p=.03)$, indicating that the relation between extraversion breeding values and age of death became less negative over time (details of these models are provided in Appendix 2: Tables 13-15). In other words, the costs of extraversion, in terms of shorter lifespan, decreased across historical period.

\section{Discussion}

Several causes of heritable individual differences have been proposed to explain the maintenance of genetic variation in human personality (Gangestad, 2010). The current study tested predictions derived from these mechanisms by examining the relations between individual differences in personality and RS success in a traditional population.

Personality Assessment. The five-factor model found for Western populations was a poor fit to the self-reported personality data in the Ache. A comparison of other-reports to self-reported data 
indicated that two factors, openness to experience and conscientiousness, were measured consistently across raters, whereas the other personality dimensions showed no inter-rater agreement. It is unclear whether the five-factor model was a poor fit because the Ache have different personality configurations than other populations, because of issues with the translation of the items, or because of issues with the 5 point scale on which participants rated items. The heritability of these personality traits were, nevertheless, mostly consistent with that found in Western societies (Bouchard \& Loehlin, 2001).

Phenotypic Personality and RS. Similar to Alvergne and colleagues (Alvergne, et al., 2010), the current study found a positive relation between extraversion and RS in men, although this effect was only marginally significant. However, evidence for most of the evolutionary mechanisms tested in the current study was generally weak; of the 14 statistical tests, 2 yielded significant results (expected by chance $=0.7$ ), and 4 total yielded significant or marginally significant (i.e., $p<0.10)$ results $($ expected by chance $=1.4$, Table 4$)$. When restricted to fitness related statistical tests only, 0 out of 12 tests yielded significant results (expected by chance $=$ $0.6)$, and 2 yielded significant or marginally significant results (expected by chance $=1.2)$. Assortative Mating. Of the two personality factors on which data were available for both sexes, that is, conscientiousness and openness, Ache individuals mated assortatively on both. These correlations, 0.41 and 0.43 , are larger than correlations between couples in Western societies (Zietsch, et al., 2011), but similar to findings by Alvergne and colleagues (Alvergne, et al., 2010). The exact processes underlying high assortative mating on these aspects of personality is unclear and warrants further investigation. One potential explanation is that individuals with similar levels of personality traits form higher quality and longer lasting relationships (29). In 
this case, being similar to one's partner on personality could increase one's reproductive success, regardless of the individual level effects of personality, and a preference for similarity would be selected. Regardless of effects on RS, assortative mating could contribute to the maintenance of heritable variation in these two dimensions of personality.

Personality Breeding Values and RS. Analyses on breeding values allowed for comparisons across time periods, which increased the number of significant relations between personality and RS, consistent with temporal variation in selection pressures. Evidence for most of the evolutionary mechanisms tested in these analyses was stronger than in the phenotypic analyses; of the 40 statistical tests reported in Table 6,11 yielded significant results (expected by chance $=$ $\left.2 ; p=2.9^{*} 10^{-6}\right)$. Also, results from the deceased and living individuals were similar in some respects.

For living individuals, higher agreeableness was associated with higher reproductive success in the forest period, and this relation was attenuated in the reservation period. For deceased individuals, agreeableness was not significantly associated with reproductive success in the forest period, but in comparison higher agreeableness was associated with lower reproductive success during the reservation period.

For living individuals, higher conscientiousness was associated with lower reproductive success in the forest period, and this cost to conscientiousness was attenuated in the reservation period. For deceased individuals, conscientiousness was not significantly associated with reproductive 
success in the forest period, but in comparison higher conscientiousness was associated with higher reproductive success during the contact period.

These results suggest that the relation between personality and RS changed across historical periods for this population. Agreeableness was more adaptive in previous generations of Ache individuals than in current generations, and conscientiousness was less adaptive in previous generations of Ache individuals than in current generations. Overall, the results provide the most consistent evidence for temporal variation in selection pressures on personality.

Limitations and Future Directions. The current study suffered from some important limitations. First, the phenotypic sample size was small, perhaps too small to detect small potentially evolutionarily significant relations between personality and RS. Also, as a result, the current study was not able to measure relations between personality and RS at the genetic level, at which selection actually operates.

Although the breeding value analyses addressed important methodological limitations associated with using RS as a dependent variable, it has some potentially major limitations. First, if the animal model used to estimate the breeding values is incorrect, conclusions derived from the breeding value analyses will not be robust. Specifically, these models may be biased toward the environmental correlation between personality and RS, whereas selection can only operate under the condition that there is a significant genetic correlation between personality and RS (Hadfield et al., 2010). These models should be interpreted with caution and should not be interpreted as evidence of actual selection on personality. Future research using larger samples can address 
these problems by measuring the genetic correlations between personality traits and fitness using the methods described by Hadfield and colleagues (2010), and compare these values to the correlations observed in the current study. Breeding value estimates are less reliable in early generations than in current generations, though regressions of RS on breeding values were weighted by the inverse of each observation's standard error to adjust for this, and models that assessed period as a moderator of the effect of personality on RS found effects of personality in the forest period, so this limitation did not completely limit the study's power to find effects in early generations. It is possible that the genes affecting personality in one generation will affect personality differently in another. For example, if extraversion is a downstream effect of the traits that enhance one's mate value (Lukaszewski \& Roney, 2011), and these traits changed in the Ache as they transitioned from foraging life to reservation life. Similarly, it is possible that personality is expressed differently in different social conditions. For example, high conscientiousness may increase time one spends foraging in a foraging population, but increase the amount of time one spends doing wage labor in a developing society; these tasks may have had different effects on reproductive success. Therefore, while the current study found the most support for temporal variation in selection pressures, it is possible that the last few generations of Ache faced an extreme case of change in selection pressures, as they faced a tumultuous transition period on route to a substantial change in lifestyle. It would be helpful to know whether the findings would have been similar in a foraging population with a more apparently stable recent history.

Future studies should seek to continue to assess of construct validity when measuring personality and attempt to use genetically informed analyses. Using larger samples would allow for the 
measurement of the genetic covariance between personality and RS, and would increase the probability of finding smaller, potentially evolutionarily relevant, effects. 
Appendix 1: Regression Tables for Phenotypic Analyses

Table 5. Regression Tables for Phenotypic Analyses: Models controlling for sex and age

\begin{tabular}{|c|c|c|c|c|c|}
\hline & $\begin{array}{l}\text { Estimate } \\
\text { (S.E.) }\end{array}$ & $\begin{array}{l}\text { Estimate } \\
\text { (S.E.) }\end{array}$ & $\begin{array}{l}\text { Estimate } \\
\text { (S.E.) }\end{array}$ & $\begin{array}{l}\text { Estimate } \\
\text { (S.E.) }\end{array}$ & $\begin{array}{l}\text { Estimate } \\
\text { (S.E.) }\end{array}$ \\
\hline (Intercept) & $\begin{array}{l}0.315 \\
(0.452)\end{array}$ & $\begin{array}{l}0.321 \\
(0.454)\end{array}$ & $\begin{array}{l}-2.284 \\
(1.24)\end{array}$ & $\begin{array}{l}-1.058 \\
(1.44)\end{array}$ & $\begin{array}{l}-0.368 \\
(1.649)\end{array}$ \\
\hline $\mathrm{O}$ & $\begin{array}{l}-0.017 \\
(0.112)\end{array}$ & . & 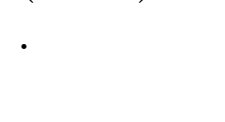 & . & . \\
\hline Sex & $\begin{array}{l}-1.095^{*} \\
(0.424)\end{array}$ & $\begin{array}{c}-1.102^{*} \\
(0.416)\end{array}$ & . & . & . \\
\hline Age & $\begin{array}{l}0.01 \\
(0.011)\end{array}$ & $\begin{array}{l}0.01 \\
(0.011)\end{array}$ & $\begin{array}{l}0.013 \\
(0.017)\end{array}$ & $\begin{array}{l}0.01 \\
(0.019)\end{array}$ & $\begin{array}{l}0.009 \\
(0.021)\end{array}$ \\
\hline $\mathrm{C}$ & . & $\begin{array}{c}-0.015 \\
(0.11)\end{array}$ & . & . & . \\
\hline $\mathrm{E}$ & . & . & $\begin{array}{l}0.437 \\
(0.234)\end{array}$ & . & . \\
\hline A & . & . & . & $\begin{array}{l}0.095 \\
(0.279)\end{array}$ & . \\
\hline $\mathrm{N}$ & . & . & . & . & $\begin{array}{l}-0.088 \\
(0.327)\end{array}$ \\
\hline $\mathrm{N}$ & 143 & 143 & 73 & 71 & 66 \\
\hline$R M S E$ & 2.201 & 2.201 & 2.586 & 2.683 & 2.756 \\
\hline$R^{2}$ & 0.051 & 0.051 & 0.051 & 0.005 & 0.005 \\
\hline$A I C$ & 637.421 & 637.426 & 350.801 & 346.574 & 326.036 \\
\hline
\end{tabular}


Moderation Models:

\begin{tabular}{|c|c|c|c|c|c|}
\hline & $\begin{array}{l}\text { Estimate } \\
\text { (S.E.) }\end{array}$ & $\begin{array}{l}\text { Estimate } \\
\text { (S.E.) }\end{array}$ & $\begin{array}{l}\text { Estimate } \\
\text { (S.E.) }\end{array}$ & $\begin{array}{l}\text { Estimate } \\
\text { (S.E.) }\end{array}$ & $\begin{array}{l}\text { Estimate } \\
\text { (S.E.) }\end{array}$ \\
\hline (Intercept) & $\begin{array}{l}0.211 \\
(0.457)\end{array}$ & $\begin{array}{l}0.096 \\
(0.469)\end{array}$ & $\begin{array}{l}0.477 \\
(0.458)\end{array}$ & $\begin{array}{l}0.335 \\
(0.462)\end{array}$ & $\begin{array}{l}0.392 \\
(0.459)\end{array}$ \\
\hline $\mathrm{C}$ & $\begin{array}{l}-0.281 \\
(0.2)\end{array}$ & . & $\begin{array}{l}-0.003 \\
(0.109)\end{array}$ & . & $\begin{array}{l}0.028 \\
(0.166)\end{array}$ \\
\hline Sex & $\begin{array}{c}-1.047^{*} \\
(0.415)\end{array}$ & $\begin{array}{c}-1.003^{*} \\
(0.425)\end{array}$ & $\begin{array}{c}-1.046^{*} \\
(0.413)\end{array}$ & $\begin{array}{c}-1.089^{*} \\
(0.427)\end{array}$ & $\begin{array}{l}-1.071^{*} \\
(0.424)\end{array}$ \\
\hline Age & $\begin{array}{l}0.011 \\
(0.011)\end{array}$ & $\begin{array}{l}0.012 \\
(0.011)\end{array}$ & $\begin{array}{l}0.013 \\
(0.011)\end{array}$ & $\begin{array}{l}0.01 \\
(0.011)\end{array}$ & $\begin{array}{l}0.012 \\
(0.011)\end{array}$ \\
\hline $\mathrm{C}^{*}$ Sex & $\begin{array}{l}0.373 \\
(0.236)\end{array}$ & . & . & . & . \\
\hline $\mathrm{O}$ & . & $\begin{array}{l}-0.312 \\
(0.214)\end{array}$ & . & $\begin{array}{l}-0.015 \\
(0.113)\end{array}$ & $\begin{array}{l}-0.038 \\
(0.169)\end{array}$ \\
\hline O*Sex & . & $\begin{array}{l}0.407 \\
(0.251)\end{array}$ & . & . & . \\
\hline$C^{2}$ & . & . & $\begin{array}{l}-0.103 \\
(0.054)\end{array}$ & . & . \\
\hline$O^{2}$ & . & . & . & $\begin{array}{l}-0.012 \\
(0.053)\end{array}$ & . \\
\hline $\mathrm{C}^{*} \mathrm{O}$ & . & . & . & . & $\begin{array}{l}-0.084 \\
(0.057)\end{array}$ \\
\hline $\mathrm{N}$ & 143 & 143 & 143 & 143 & 143 \\
\hline$R M S E$ & 2.19 & 2.188 & 2.181 & 2.209 & 2.2 \\
\hline$R^{2}$ & 0.068 & 0.069 & 0.075 & 0.052 & 0.066 \\
\hline$A I C$ & 636.86 & 636.724 & 635.764 & 639.367 & 639.141 \\
\hline
\end{tabular}


Appendix 2: Regression Tables for Breeding Value and Age of Death Analyses

Table 7. Regression Tables for Breeding Value Analyses: Alive individuals, models controlling for sex

\begin{tabular}{llllll}
\hline & $\begin{array}{l}\text { Estimate } \\
(\text { S.E. })\end{array}$ & $\begin{array}{l}\text { Estimate } \\
\text { (S.E. })\end{array}$ & $\begin{array}{l}\text { Estimate } \\
(\text { S.E. })\end{array}$ & $\begin{array}{l}\text { Estimate } \\
(\text { S.E. })\end{array}$ & $\begin{array}{l}\text { Estimate } \\
(\text { S.E. })\end{array}$ \\
\hline \hline (Intercept) & $0.825^{*}$ & $0.765^{*}$ & $0.83^{*}$ & $0.792^{*}$ & $0.767^{*}$ \\
& $(0.158)$ & $(0.154)$ & $(0.148)$ & $(0.152)$ & $(0.147)$ \\
$\mathrm{E}$ & 0.189 & $\cdot$ & $\cdot$ & $\cdot$ & $\cdot$ \\
& $(0.203)$ & & & & \\
$\mathrm{Sex}$ & $-0.474^{*}$ & $-0.561^{*}$ & $-0.766^{*}$ & $-0.617^{*}$ & $-0.766^{*}$ \\
& $(0.207)$ & $(0.204)$ & $(0.2)$ & $(0.203)$ & $(0.198)$ \\
$\mathrm{A}$ & $\cdot$ & $0.645^{*}$ & $\cdot$ & $\cdot$ & $\cdot$ \\
& & $(0.271)$ & & & \\
$\mathrm{C}$ & $\cdot$ & $\cdot$ & 0.039 & $\cdot$ & $\cdot$ \\
& & & $(0.324)$ & & \\
$\mathrm{N}$ & $\cdot$ & $\cdot$ & $\cdot$ & -0.172 & $\cdot$ \\
& & & & $(0.348)$ & \\
$\mathrm{O}$ & $\cdot$ & $\cdot$ & $\cdot$ & $\cdot$ & -0.4 \\
& & & & & $(0.862)$ \\
\hline $\mathrm{N}$ & 741 & 741 & 741 & 741 & 741 \\
$R M S E$ & 2.738 & 2.94 & 2.915 & 3.144 & 3.706 \\
$R^{2}$ & 0.008 & 0.018 & 0.02 & 0.013 & 0.02 \\
$A I C$ & 3643.314 & 3612.701 & 3583.666 & 3605.963 & 3570.393 \\
\hline \hline$* p \leq 0.05$ & & & & &
\end{tabular}


Table 8. Regression Tables for Breeding Value Analyses: Alive individuals, personality*sex

\begin{tabular}{|c|c|c|c|c|c|}
\hline & $\begin{array}{l}\text { Estimate } \\
\text { (S.E.) }\end{array}$ & $\begin{array}{l}\text { Estimate } \\
\text { (S.E.) }\end{array}$ & $\begin{array}{l}\text { Estimate } \\
\text { (S.E.) }\end{array}$ & $\begin{array}{l}\text { Estimate } \\
\text { (S.E.) }\end{array}$ & $\begin{array}{l}\text { Estimate } \\
\text { (S.E.) }\end{array}$ \\
\hline (Intercept) & $\begin{array}{l}0.818^{*} \\
(0.158)\end{array}$ & $\begin{array}{l}0.74^{*} \\
(0.157)\end{array}$ & $\begin{array}{l}0.806^{*} \\
(0.15)\end{array}$ & $\begin{array}{l}0.791^{*} \\
(0.152)\end{array}$ & $\begin{array}{l}0.73^{*} \\
(0.148)\end{array}$ \\
\hline $\mathrm{E}$ & $\begin{array}{l}-0.336 \\
(0.473)\end{array}$ & $\cdot$ & . & . & . \\
\hline Sex & $\begin{array}{c}-0.466^{*} \\
(0.207)\end{array}$ & $\begin{array}{l}-0.528^{*} \\
(0.207)\end{array}$ & $\begin{array}{l}-0.736^{*} \\
(0.201)\end{array}$ & $\begin{array}{c}-0.615^{*} \\
(0.203)\end{array}$ & $\begin{array}{l}-0.73^{*} \\
(0.199)\end{array}$ \\
\hline $\mathrm{E}^{*}$ Sex & $\begin{array}{l}0.643 \\
(0.523)\end{array}$ & . & . & . & . \\
\hline A & . & $\begin{array}{l}1.041 \\
(0.543)\end{array}$ & . & . & . \\
\hline$A^{*}$ Sex & . & $\begin{array}{l}-0.529 \\
(0.627)\end{array}$ & . & . & . \\
\hline $\mathrm{C}$ & . & . & $\begin{array}{l}-0.511 \\
(0.575)\end{array}$ & . & . \\
\hline $\mathrm{C}^{*} \mathrm{Sex}$ & . & . & $\begin{array}{l}0.806 \\
(0.696)\end{array}$ & . & . \\
\hline $\mathrm{N}$ & . & . & . & $\begin{array}{l}-0.26 \\
(0.673)\end{array}$ & . \\
\hline $\mathrm{N}^{*}$ Sex & . & . & . & $\begin{array}{l}0.12 \\
(0.786)\end{array}$ & . \\
\hline $\mathrm{O}$ & . & . & . & . & $\begin{array}{l}-2.848 \\
(1.503)\end{array}$ \\
\hline O*Sex & . & . & . & . & $\begin{array}{l}3.642^{*} \\
(1.833)\end{array}$ \\
\hline $\mathrm{N}$ & 741 & 741 & 741 & 741 & 741 \\
\hline$R M S E$ & 2.737 & 2.941 & 2.914 & 3.146 & 3.698 \\
\hline$R^{2}$ & 0.01 & 0.019 & 0.021 & 0.013 & 0.026 \\
\hline$A I C$ & 3643.796 & 3613.986 & 3584.319 & 3607.94 & 3568.433 \\
\hline
\end{tabular}


Table 9. Regression Tables for Breeding Value Analyses: Alive individuals, personality*historical period

\begin{tabular}{|c|c|c|c|c|c|}
\hline & $\begin{array}{l}\text { Estimate } \\
\text { (S.E.) }\end{array}$ & $\begin{array}{l}\text { Estimate } \\
\text { (S.E.) }\end{array}$ & $\begin{array}{l}\text { Estimate } \\
\text { (S.E.) }\end{array}$ & $\begin{array}{l}\text { Estimate } \\
\text { (S.E.) }\end{array}$ & $\begin{array}{l}\text { Estimate } \\
\text { (S.E.) }\end{array}$ \\
\hline (Intercept) & $\begin{array}{c}-1.877^{*} \\
(0.409)\end{array}$ & $\begin{array}{c}-2.283^{*} \\
(0.412)\end{array}$ & $\begin{array}{c}-2.624^{*} \\
(0.423)\end{array}$ & $\begin{array}{c}-2.256^{*} \\
(0.411)\end{array}$ & $\begin{array}{l}-2.52^{*} \\
(0.409)\end{array}$ \\
\hline $\mathrm{E}$ & $\begin{array}{l}0.288 \\
(0.603)\end{array}$ & . & . & . & . \\
\hline Contact & $\begin{array}{l}3.59^{*} \\
(0.442)\end{array}$ & $\begin{array}{l}3.88^{*} \\
(0.446)\end{array}$ & $\begin{array}{l}4.219^{*} \\
(0.458)\end{array}$ & $\begin{array}{l}3.877^{*} \\
(0.445)\end{array}$ & $\begin{array}{l}4.036^{*} \\
(0.445)\end{array}$ \\
\hline Reservation & $\begin{array}{l}2.652^{*} \\
(0.402)\end{array}$ & $\begin{array}{l}3.038^{*} \\
(0.408)\end{array}$ & $\begin{array}{l}3.47^{*} \\
(0.419)\end{array}$ & $\begin{array}{l}3.034^{*} \\
(0.407)\end{array}$ & $\begin{array}{l}3.316^{*} \\
(0.406)\end{array}$ \\
\hline Sex & $\begin{array}{l}-0.424^{*} \\
(0.2)\end{array}$ & $\begin{array}{c}-0.507^{*} \\
(0.195)\end{array}$ & $\begin{array}{c}-0.72^{*} \\
(0.19)\end{array}$ & $\begin{array}{c}-0.563^{*} \\
(0.194)\end{array}$ & $\begin{array}{c}-0.722^{*} \\
(0.189)\end{array}$ \\
\hline $\mathrm{E}^{*}$ Contact & $\begin{array}{l}-0.098 \\
(0.703)\end{array}$ & . & . & . & . \\
\hline $\mathrm{E}^{*}$ Reservation & $\begin{array}{l}-0.138 \\
(0.653)\end{array}$ & . & . & . & . \\
\hline $\mathrm{A}$ & . & $\begin{array}{l}2.441^{*} \\
(1.053)\end{array}$ & . & . & . \\
\hline A*Contact & . & $\begin{array}{l}-1.202 \\
(1.162)\end{array}$ & . & . & . \\
\hline A*Reservation & . & $\begin{array}{l}-2.138 \\
(1.1)\end{array}$ & . & . & . \\
\hline $\mathrm{C}$ & . & . & $\begin{array}{l}-2.381^{*} \\
(1.154)\end{array}$ & . & . \\
\hline $\mathrm{C}^{*}$ Contact & . & . & $\begin{array}{l}1.772 \\
(1.329)\end{array}$ & . & . \\
\hline $\mathrm{C}^{*}$ Reservation & . & . & $\begin{array}{l}2.706^{*} \\
(1.211)\end{array}$ & . & . \\
\hline $\mathrm{N}$ & . & . & . & $\begin{array}{l}-0.674 \\
(0.911)\end{array}$ & . \\
\hline $\mathrm{N}^{*}$ Contact & . & . & . & $\begin{array}{l}-0.53 \\
(1.085)\end{array}$ & . \\
\hline $\mathrm{N}^{*}$ Reservation & . & . & . & $\begin{array}{l}0.906 \\
(1.016)\end{array}$ & . \\
\hline $\mathrm{O}$ & . & . & . & . & $\begin{array}{l}1.014 \\
(3.168)\end{array}$ \\
\hline $\mathrm{O}^{*}$ Contact & . & . & . & . & $\begin{array}{l}-3.457 \\
(3.57)\end{array}$ \\
\hline O*Reservation & . & . & . & . & $\begin{array}{l}-1.13 \\
(3.317)\end{array}$ \\
\hline $\mathrm{N}$ & 741 & 741 & 741 & 741 & 741 \\
\hline$R M S E$ & 2.629 & 2.8 & 2.76 & 2.992 & 3.505 \\
\hline$R^{2}$ & 0.091 & 0.114 & 0.126 & 0.111 & 0.128 \\
\hline$A I C$ & 3587.072 & 3544.377 & 3506.835 & 3536.315 & 3491.927 \\
\hline
\end{tabular}


Table 10. Regression Tables for Breeding Value Analyses: Deceased individuals, models controlling for sex

\begin{tabular}{|c|c|c|c|c|c|}
\hline & $\begin{array}{l}\text { Estimate } \\
\text { (S.E.) }\end{array}$ & $\begin{array}{l}\text { Estimate } \\
\text { (S.E.) }\end{array}$ & $\begin{array}{l}\text { Estimate } \\
\text { (S.E.) }\end{array}$ & $\begin{array}{l}\text { Estimate } \\
\text { (S.E.) }\end{array}$ & $\begin{array}{l}\text { Estimate } \\
\text { (S.E.) }\end{array}$ \\
\hline (Intercept) & $\begin{array}{l}1.497^{*} \\
(0.034)\end{array}$ & $\begin{array}{l}1.499^{*} \\
(0.031)\end{array}$ & $\begin{array}{l}1.489^{*} \\
(0.031)\end{array}$ & $\begin{array}{l}1.493^{*} \\
(0.029)\end{array}$ & $\begin{array}{l}1.488^{*} \\
(0.024)\end{array}$ \\
\hline $\mathrm{E}$ & $\begin{array}{l}-0.041 \\
(0.073)\end{array}$ & r & . & . & . \\
\hline Sex & $\begin{array}{l}-0.316^{*} \\
(0.049)\end{array}$ & $\begin{array}{l}-0.33^{*} \\
(0.045)\end{array}$ & $\begin{array}{l}-0.349^{*} \\
(0.044)\end{array}$ & $\begin{array}{c}-0.336^{*} \\
(0.041)\end{array}$ & $\begin{array}{l}-0.359^{*} \\
(0.034)\end{array}$ \\
\hline A & . & $\begin{array}{l}-0.123 \\
(0.069)\end{array}$ & . & . & . \\
\hline $\mathrm{C}$ & . & $\cdot$ & $\begin{array}{l}-0.129 \\
(0.098)\end{array}$ & . & . \\
\hline $\mathrm{N}$ & . & . & . & $\begin{array}{c}-0.194^{*} \\
(0.083)\end{array}$ & . \\
\hline $\mathrm{O}$ & . & . & . & . & $\begin{array}{l}-0.409^{*} \\
(0.182)\end{array}$ \\
\hline $\mathrm{N}$ & 484 & 484 & 484 & 484 & 484 \\
\hline Deviance & 1705.041 & 2063.392 & 2107.138 & 2394.401 & 3504.412 \\
\hline$-2 L L R\left(\right.$ Model $\left.\chi^{2}\right)$ & $41.555^{*}$ & $56.728^{*}$ & $63.649^{*}$ & $70.33^{*}$ & $111.729^{*}$ \\
\hline$A I C$ & 2755.696 & 3335.255 & 3406.448 & 3870.598 & 5660.55 \\
\hline
\end{tabular}


Table 11. Regression Tables for Breeding Value Analyses: Deceased individuals, personality*sex

\begin{tabular}{|c|c|c|c|c|c|}
\hline & $\begin{array}{l}\text { Estimate } \\
\text { (S.E.) }\end{array}$ & $\begin{array}{l}\text { Estimate } \\
\text { (S.E.) }\end{array}$ & $\begin{array}{l}\text { Estimate } \\
\text { (S.E.) }\end{array}$ & $\begin{array}{l}\text { Estimate } \\
\text { (S.E.) }\end{array}$ & $\begin{array}{l}\text { Estimate } \\
\text { (S.E.) }\end{array}$ \\
\hline (Intercept) & $\begin{array}{l}1.499^{*} \\
(0.034)\end{array}$ & $\begin{array}{l}1.491^{*} \\
(0.031)\end{array}$ & $\begin{array}{l}1.491^{*} \\
(0.031)\end{array}$ & $\begin{array}{l}1.493^{*} \\
(0.029)\end{array}$ & $\begin{array}{l}1.488^{*} \\
(0.024)\end{array}$ \\
\hline $\mathrm{E}$ & $\begin{array}{l}0.086 \\
(0.111)\end{array}$ & • & . & . & . \\
\hline Sex & $\begin{array}{l}-0.322^{*} \\
(0.049)\end{array}$ & $\begin{array}{c}-0.323^{*} \\
(0.045)\end{array}$ & $\begin{array}{l}-0.355^{*} \\
(0.045)\end{array}$ & $\begin{array}{l}-0.334^{*} \\
(0.042)\end{array}$ & $\begin{array}{c}-0.358^{*} \\
(0.035)\end{array}$ \\
\hline$E^{*}$ Sex & $\begin{array}{l}-0.227 \\
(0.147)\end{array}$ & & & 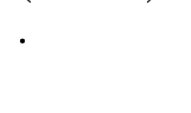 & . \\
\hline A & . & $\begin{array}{l}0.103 \\
(0.099)\end{array}$ & . & . & . \\
\hline$A^{*}$ Sex & . & $\begin{array}{c}-0.426^{*} \\
(0.135)\end{array}$ & . & . & . \\
\hline $\mathrm{C}$ & . & . & $\begin{array}{l}-0.057 \\
(0.134)\end{array}$ & . & . \\
\hline $\mathrm{C}^{*} \mathrm{Sex}$ & . & . & $\begin{array}{l}-0.155 \\
(0.196)\end{array}$ & . & . \\
\hline $\mathrm{N}$ & . & . & . & $\begin{array}{c}-0.248^{*} \\
(0.118)\end{array}$ & . \\
\hline $\mathrm{N}^{*} \mathrm{Sex}$ & . & . & . & $\begin{array}{l}0.107 \\
(0.165)\end{array}$ & . \\
\hline $\mathrm{O}$ & . & . & . & . & $\begin{array}{c}-0.504^{*} \\
(0.254)\end{array}$ \\
\hline O*Sex & . & . & . & . & $\begin{array}{l}0.194 \\
(0.365)\end{array}$ \\
\hline $\mathrm{N}$ & 484 & 484 & 484 & 484 & 484 \\
\hline Deviance & 1702.654 & 2053.609 & 2106.513 & 2393.979 & 3504.128 \\
\hline$-2 L L R\left(\right.$ Model $\left.\chi^{2}\right)$ & $43.942^{*}$ & $66.511^{*}$ & $64.275^{*}$ & $70.752^{*}$ & $112.013^{*}$ \\
\hline$A I C$ & 2755.309 & 3327.472 & 3407.822 & 3872.177 & 5662.267 \\
\hline
\end{tabular}


Table 12. Regression Tables for Breeding Value Analyses: Deceased individuals, personality*historical period

\begin{tabular}{|c|c|c|c|c|c|}
\hline & $\begin{array}{l}\text { Estimate } \\
\text { (S.E.) }\end{array}$ & $\begin{array}{l}\text { Estimate } \\
\text { (S.E.) }\end{array}$ & $\begin{array}{l}\text { Estimate } \\
\text { (S.E.) }\end{array}$ & $\begin{array}{l}\text { Estimate } \\
\text { (S.E.) }\end{array}$ & $\begin{array}{l}\text { Estimate } \\
\text { (S.E.) }\end{array}$ \\
\hline (Intercept) & $\begin{array}{l}1.776^{*} \\
(0.036)\end{array}$ & $\begin{array}{l}1.778^{*} \\
(0.033)\end{array}$ & $\begin{array}{l}1.763^{*} \\
(0.032)\end{array}$ & $\begin{array}{l}1.771^{*} \\
(0.03)\end{array}$ & $\begin{array}{l}1.766^{*} \\
(0.025)\end{array}$ \\
\hline $\mathrm{E}$ & $\begin{array}{l}-0.128 \\
(0.081)\end{array}$ & . & . & . & . \\
\hline Contact & $\begin{array}{c}-0.942^{*} \\
(0.075)\end{array}$ & $\begin{array}{l}-0.95^{*} \\
(0.068)\end{array}$ & $\begin{array}{c}-0.931^{*} \\
(0.067)\end{array}$ & $\begin{array}{c}-0.949^{*} \\
(0.064)\end{array}$ & $\begin{array}{c}-0.928^{*} \\
(0.052)\end{array}$ \\
\hline Reservation & $\begin{array}{c}-1.763^{*} \\
(0.172)\end{array}$ & $\begin{array}{c}-1.954^{*} \\
(0.18)\end{array}$ & $\begin{array}{l}-1.763^{*} \\
(0.155)\end{array}$ & $\begin{array}{l}-1.81^{*} \\
(0.148)\end{array}$ & $\begin{array}{c}-1.794^{*} \\
(0.121)\end{array}$ \\
\hline Sex & $\begin{array}{c}-0.362^{*} \\
(0.049)\end{array}$ & $\begin{array}{l}-0.368^{*} \\
(0.045)\end{array}$ & $\begin{array}{l}-0.385^{*} \\
(0.044)\end{array}$ & $\begin{array}{l}-0.375^{*} \\
(0.042)\end{array}$ & $\begin{array}{c}-0.396^{*} \\
(0.035)\end{array}$ \\
\hline $\mathrm{E}^{*}$ Contact & $\begin{array}{l}0.462^{*} \\
(0.22)\end{array}$ & . & . & . & . \\
\hline$E^{*}$ Reservation & $\begin{array}{l}1^{*} \\
(0.507)\end{array}$ & . & . & . & . \\
\hline A & . & $\begin{array}{l}-0.08 \\
(0.079)\end{array}$ & . & . & . \\
\hline $\mathrm{A}^{*}$ Contact & . & $\begin{array}{c}-0.373^{*} \\
(0.185)\end{array}$ & . & . & . \\
\hline $\mathrm{A}^{*}$ Reservation & . & $\begin{array}{c}-1.545^{*} \\
(0.432)\end{array}$ & . & . & . \\
\hline $\mathrm{C}$ & . & . & $\begin{array}{l}-0.175 \\
(0.105)\end{array}$ & . & . \\
\hline $\mathrm{C}^{*}$ Contact & . & . & $\begin{array}{l}0.799^{*} \\
(0.302)\end{array}$ & . & . \\
\hline $\mathrm{C}^{*}$ Reservation & . & . & $\begin{array}{l}0.589 \\
(0.683)\end{array}$ & . & . \\
\hline $\mathrm{N}$ & . & . & . & $\begin{array}{c}-0.187^{*} \\
(0.092)\end{array}$ & . \\
\hline $\mathrm{N}^{*}$ Contact & . & . & . & $\begin{array}{l}0.514^{*} \\
(0.222)\end{array}$ & . \\
\hline $\mathrm{N}^{*}$ Reservation & . & . & . & $\begin{array}{l}0.61 \\
(0.571)\end{array}$ & . \\
\hline $\mathrm{O}$ & . & . & . & . & $\begin{array}{l}-0.25 \\
(0.192)\end{array}$ \\
\hline $\mathrm{O} *$ Contact & . & . & . & . & $\begin{array}{l}0.245 \\
(0.591)\end{array}$ \\
\hline O*Reservation & . & . & . & . & $\begin{array}{l}0.563 \\
(1.301)\end{array}$ \\
\hline $\mathrm{N}$ & 484 & 484 & 484 & 484 & 484 \\
\hline Deviance & 1346.074 & 1617.108 & 1670.274 & 1896.23 & 2793.918 \\
\hline$-2 L L R$ & $400.522^{*}$ & $503.012^{*}$ & $500.513^{*}$ & $568.501^{*}$ & $822.223^{*}$ \\
\hline$A I C$ & 2404.729 & 2896.971 & 2977.584 & 3380.427 & 4958.057 \\
\hline
\end{tabular}


Table 13: Age of Death Analyses: models controlling for sex

\begin{tabular}{llllll}
\hline & $\begin{array}{l}\text { Estimate } \\
(\text { S.E. })\end{array}$ & $\begin{array}{l}\text { Estimate } \\
(\text { S.E. })\end{array}$ & $\begin{array}{l}\text { Estimate } \\
(\text { S.E. })\end{array}$ & $\begin{array}{l}\text { Estimate } \\
(\text { S.E. })\end{array}$ & $\begin{array}{l}\text { Estimate } \\
(\text { S.E. })\end{array}$ \\
\hline \hline (Intercept) & $43.983^{*}$ & $44.157^{*}$ & $43.954^{*}$ & $44.141^{*}$ & $44.138^{*}$ \\
& $(1.251)$ & $(1.258)$ & $(1.247)$ & $(1.246)$ & $(1.243)$ \\
$\mathrm{E}$ & $-5.765^{*}$ & $\cdot$ & $\cdot$ & $\cdot$ & $\cdot$ \\
& $(2.452)$ & & & & \\
$\mathrm{Sex}$ & -1.642 & -1.792 & -2.116 & -1.93 & -2.335 \\
& $(1.667)$ & $(1.674)$ & $(1.661)$ & $(1.663)$ & $(1.661)$ \\
$\mathrm{A}$ & $\cdot$ & -1.323 & $\cdot$ & $\cdot$ & $\cdot$ \\
& & $(2.565)$ & & & \\
$\mathrm{C}$ & $\cdot$ & $\cdot$ & $-7.353^{*}$ & $\cdot$ & $\cdot$ \\
& & & $(3.663)$ & & $\cdot$ \\
$\mathrm{N}$ & $\cdot$ & $\cdot$ & $\cdot$ & $-7.334^{*}$ & $\cdot$ \\
& & & & $(3.219)$ & \\
$\mathrm{O}$ & $\cdot$ & $\cdot$ & $\cdot$ & $\cdot$ & $-19.65^{*}$ \\
& & & & & $(8.739)$ \\
\hline $\mathrm{N}$ & 484 & 484 & 484 & 484 & 484 \\
$R M S E$ & 17.331 & 19.185 & 19.321 & 20.57 & 24.921 \\
$R^{2}$ & 0.013 & 0.003 & 0.011 & 0.013 & 0.014 \\
$A I C$ & 4189.141 & 4191.678 & 4184.003 & 4185.123 & 4182.289 \\
\hline \hline$* p \leq 0.05$ & & & & &
\end{tabular}


Table 14: Age of Death Analyses personality*sex

\begin{tabular}{|c|c|c|c|c|c|}
\hline & $\begin{array}{l}\text { Estimate } \\
\text { (S.E.) }\end{array}$ & $\begin{array}{l}\text { Estimate } \\
\text { (S.E.) }\end{array}$ & $\begin{array}{l}\text { Estimate } \\
\text { (S.E.) }\end{array}$ & $\begin{array}{l}\text { Estimate } \\
\text { (S.E.) }\end{array}$ & $\begin{array}{l}\text { Estimate } \\
\text { (S.E.) }\end{array}$ \\
\hline (Intercept) & $\begin{array}{l}44.033^{*} \\
(1.253)\end{array}$ & $\begin{array}{l}44.045^{*} \\
(1.264)\end{array}$ & $\begin{array}{l}44.026^{*} \\
(1.252)\end{array}$ & $\begin{array}{l}44.138^{*} \\
(1.247)\end{array}$ & $\begin{array}{l}44.138^{*} \\
(1.244)\end{array}$ \\
\hline $\mathrm{E}$ & $\begin{array}{l}-3.181 \\
(4.022)\end{array}$ & . & . & . & . \\
\hline Sex & $\begin{array}{l}-1.736 \\
(1.672)\end{array}$ & $\begin{array}{l}-1.648 \\
(1.682)\end{array}$ & $\begin{array}{l}-2.261 \\
(1.673)\end{array}$ & $\begin{array}{l}-1.93 \\
(1.664)\end{array}$ & $\begin{array}{l}-2.361 \\
(1.664)\end{array}$ \\
\hline $\mathrm{E}^{*}$ Sex & $\begin{array}{l}-4.115 \\
(5.075)\end{array}$ & . & . & . & . \\
\hline A & . & $\begin{array}{l}1.453 \\
(4.026)\end{array}$ & . & . & . \\
\hline$A^{*}$ Sex & . & $\begin{array}{l}-4.675 \\
(5.224)\end{array}$ & . & . & . \\
\hline $\mathrm{C}$ & . & . & $\begin{array}{l}-4.321 \\
(5.457)\end{array}$ & . & . \\
\hline $\mathrm{C}^{*}$ Sex & . & . & $\begin{array}{l}-5.522 \\
(7.364)\end{array}$ & . & . \\
\hline $\mathrm{N}$ & . & . & . & $\begin{array}{l}-6.491 \\
(5.041)\end{array}$ & . \\
\hline $\mathrm{N}^{*}$ Sex & . & . & . & $\begin{array}{l}-1.424 \\
(6.554)\end{array}$ & . \\
\hline $\mathrm{O}$ & . & . & . & . & $\begin{array}{l}-15.772 \\
(13.323)\end{array}$ \\
\hline $\mathrm{O}^{*} \mathrm{Sex}$ & . & . & . & . & $\begin{array}{l}-6.816 \\
(17.663)\end{array}$ \\
\hline $\mathrm{N}$ & 484 & 484 & 484 & 484 & 484 \\
\hline$R M S E$ & 17.337 & 19.189 & 19.33 & 20.59 & 24.943 \\
\hline$R^{2}$ & 0.015 & 0.005 & 0.013 & 0.013 & 0.014 \\
\hline$A I C$ & 4190.478 & 4192.872 & 4185.437 & 4187.075 & 4184.139 \\
\hline
\end{tabular}


Table 15: Age of Death Analyses: personality*historical period

\begin{tabular}{|c|c|c|c|c|c|}
\hline & $\begin{array}{l}\text { Estimate } \\
\text { (S.E.) }\end{array}$ & $\begin{array}{l}\text { Estimate } \\
\text { (S.E.) }\end{array}$ & $\begin{array}{l}\text { Estimate } \\
\text { (S.E.) }\end{array}$ & $\begin{array}{l}\text { Estimate } \\
\text { (S.E.) }\end{array}$ & $\begin{array}{l}\text { Estimate } \\
\text { (S.E.) }\end{array}$ \\
\hline (Intercept) & $\begin{array}{l}51.406^{*} \\
(1.188)\end{array}$ & $\begin{array}{l}51.621^{*} \\
(1.207)\end{array}$ & $\begin{array}{l}51.352^{*} \\
(1.199)\end{array}$ & $\begin{array}{l}51.472^{*} \\
(1.193)\end{array}$ & $\begin{array}{l}51.456^{*} \\
(1.192)\end{array}$ \\
\hline $\mathrm{E}$ & $\begin{array}{l}-9.181^{*} \\
(2.625)\end{array}$ & . & 1 & . & . \\
\hline Contact & $\begin{array}{c}-19.901^{*} \\
(1.665)\end{array}$ & $\begin{array}{l}-20.078^{*} \\
(1.682)\end{array}$ & $\begin{array}{c}-19.914^{*} \\
(1.677)\end{array}$ & $\begin{array}{l}-19.97^{*} \\
(1.678)\end{array}$ & $\begin{array}{c}-19.839^{*} \\
(1.673)\end{array}$ \\
\hline Reservation & $\begin{array}{l}-21.045^{*} \\
(2.448)\end{array}$ & $\begin{array}{l}-21.332^{*} \\
(2.452)\end{array}$ & $\begin{array}{l}-20.956^{*} \\
(2.446)\end{array}$ & $\begin{array}{l}-21.082^{*} \\
(2.444)\end{array}$ & $\begin{array}{l}-20.942^{*} \\
(2.437)\end{array}$ \\
\hline Sexo & $\begin{array}{c}-2.784^{*} \\
(1.413)\end{array}$ & $\begin{array}{c}-2.824^{*} \\
(1.429)\end{array}$ & $\begin{array}{c}-3.076^{*} \\
(1.422)\end{array}$ & $\begin{array}{l}-2.881^{*} \\
(1.42)\end{array}$ & $\begin{array}{c}-3.232^{*} \\
(1.419)\end{array}$ \\
\hline $\mathrm{E}^{*}$ Contact & $\begin{array}{l}10.237^{*} \\
(4.796)\end{array}$ & 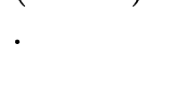 & & & \\
\hline $\mathrm{E}^{*}$ Reservation & $\begin{array}{l}10.26 \\
(6.853)\end{array}$ & . & & . & . \\
\hline A & . & $\begin{array}{l}-0.978 \\
(2.844)\end{array}$ & . & . & . \\
\hline $\mathrm{A}^{*}$ Contact & . & $\begin{array}{l}-4.819 \\
(4.93)\end{array}$ & . & . & . \\
\hline A*Reservation & . & $\begin{array}{l}1.867 \\
(6.973)\end{array}$ & . & . & . \\
\hline $\mathrm{C}$ & . & . & $\begin{array}{l}-6.422 \\
(3.776)\end{array}$ & . & . \\
\hline $\mathrm{C}^{*}$ Contact & . & . & $\begin{array}{l}0.83 \\
(7.624)\end{array}$ & . & . \\
\hline $\mathrm{C}^{*}$ Reservation & . & . & $\begin{array}{l}3.647 \\
(10.935)\end{array}$ & . & . \\
\hline $\mathrm{N}$ & . & . & . & $\begin{array}{l}-6.723 \\
(3.503)\end{array}$ & . \\
\hline $\mathrm{N}^{*}$ Contact & . & . & & $\begin{array}{l}5.363 \\
(6.163)\end{array}$ & . \\
\hline $\mathrm{N}^{*}$ Reservation & . & . & & $\begin{array}{l}1.904 \\
(9.822)\end{array}$ & \\
\hline $\mathrm{O}$ & . & . & & . & $\begin{array}{c}-15.507 \\
(8.851)\end{array}$ \\
\hline $\mathrm{O}^{*}$ Contact & . & . & & . & $\begin{array}{l}-0.144 \\
(18.768)\end{array}$ \\
\hline O*Reservation & . & . & 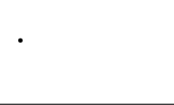 & . & $\begin{array}{l}5.128 \\
(26.952)\end{array}$ \\
\hline $\mathrm{N}$ & 484 & 484 & 484 & 484 & 484 \\
\hline$R M S E$ & 14.651 & 16.299 & 16.464 & 17.537 & 21.269 \\
\hline$R^{2}$ & 0.301 & 0.286 & 0.288 & 0.289 & 0.288 \\
\hline$A I C$ & 4030.448 & 4037.878 & 4033.071 & 4034.668 & 4032.858 \\
\hline
\end{tabular}




\section{References}

Allison, A. C. (1954). Protection afforded by sickle-cell trait against subtertian malarial infection. British medical journal, 1(4857), 290-294.

Alvergne, A., Jokela, M., \& Lummaa, V. (2010). Personality and reproductive success in a highfertility human population. Proceedings of the National Academy of Sciences of the U.S.A., 107(26), 11745-11750.

Apostolou, M. (2007). Sexual selection under parental choice: the role of parents in the evolution of human mating. Evolution and Human Behavior, 28(6), 403-409.

Belsky, J., Steinberg, L., \& Draper, P. (1991). Childhood experience, interpersonal development, and reproductive strategy: An evolutionary theory of socialization. Child Development, 62, 647-670.

Benet-Martinez, V., \& John, O. P. (1998). Los Cinco Grandes across cultures and ethnic groups: multitrait multimethod analyses of the Big Five in Spanish and English. Journal of Personality and Social Psychology, 75(3), 729-750.

Bouchard, T. J., \& Loehlin, J. C. (2001). Genes, evolution, and personality. Behavior Genetics, 31(3), 243-273.

Bouchard, C., Lesage, R., Lortie, G., Simoneau, J.A., Hamel, P., Boulay, M.R., et al. (1986). Aerobic performance in brothers dizygotic and monozygotic twins. Medicine and Science in Sports and Exercise 18, 639-46.

Buss, D. M. (2009). How can evolutionary psychology successfully explain personalityand 
individual differences? Perspectives in Psychological Science, 4, 359-366.

Buss, D. M. (2006). The evolutionary genetics of personality: Does mutation load signal relationship load? Behavioral and Brain Sciences, 29, 409.

Buss, D. M., \& Barnes, M. (1986). Preferences in human mate selection. Journal of Personality and Social Psychology, 50(3), 559-570.

Buss, D. M., et al. (1990). International preferences in selecting mates. Journal of Cross-Cultural Psychology, 21(1), 5-47.

Byrd-Craven, J., Geary, D. C., Vigil, J. M., \& Hoard, M. K. (2007). One mate or two? Life history traits and reproductive variation in low-income women. Acta Psychological Sinica, 39, 469-480.

Chagnon, N. A. (1979). Mate competition, favoring close kin, and village fissioning among the Yanomamo Indians. In N. Chagon \& W. Irons (Eds.), Evolutionary Biology of Human Social Behavior (pp. 86-132). North Scituate, Massachusetts: Duxbury Press.

Chiao, J. Y., \& Blizinsky, K. D. (2010). Culture-gene coevolution of individualism-collectivism and the serotonin transporter gene (5-HTTLPR). Proceedings of the Royal Society B: Biological Sciences, 277, 529-537.

Confer, J.C., Easton, J.A., Fleishman, D.S., Goetz, C.D., Lewis, D.M.G., Perilloux, C., \& Buss, D.M. (2010). Evolutionary Psychology: Controversies, questions, prospects, and limitations. American Psychologist, 65, 110-126.

Connelly, B. S., \& Ones, D. S. (2010). An other perspective on personality: meta-analytic 
integration of observers' accuracy and predictive validity. Psychological Bulletin, 136(6), 1092-1122.

Dingemanse, N. J., Both, C., Drent, P. J., \& Tinbergen, J. M. (2004). Fitness consequences of avian personalities in a fluctuating environment. Proceedings. Biological sciences / The Royal Society, 271(1541), 847-852.

Draper, P., \& Harpending. H. (1982). Father absence and reproductive strategy. Journal of Anthropological Research, 38, 255-272.

Eaves, L. J., Martin, N. G., Heath, A. C., Hewitt, J. K., \& Neale, M. C. (1990). Personality and reproductive fitness. Behavior Genetics, 20(5), 563-568.

Eaves, L. J., Heath, A. C., Neale, M. C., Hewitt, J. K., \& Martin, N. G. (1998). Sex differences in non-additivity in the effects of genes on personality. Twin Research and Human Genetics, $1,131-137$.

Ellis, B. J., Bates, J. E., Dodge, K. A., Fergusson, D. M., Horwood, L. J., Pettit, G. S., et al. (2003). Does father absence place daughters at special risk for early sexual activity and teenage pregnancy. Child Development, 74, 801-821.

Ellis, B. J., \& Essex, M. J. (2007). Family environments, adrenarche, and sexual maturation: A longitudinal test of a life history model. Child Development, 78, 1799-1817.

Gangestad, S. W. (2010). Evolutionary biology looks at behavior genetics. Personality and Individual Differences, 49, 289-295.

Geary, D. C. (2010). Male, female: The evolution of human sex differences (second ed). 
Washington, DC: American Psychological Association.

Hadfield, J. D., Wilson, A. J., Garant, D., Sheldon, B. C., \& Kruuk, L. E. B. (2010). The misuse of BLUP in ecology and evolution. The American Naturalist, 175, 116-125.

Hamilton, W. D., \& Zuk, M. (1982). Heritable true fitness and bright birds: A role for parasites? Science, 218, 384-387.

Hill, K., \& Hawkes, K. (1983). Neotropical hunting among the Ache of eastern Paraguay. In R. Hames \& W. Vickers (Eds.), Adaptive responses of native Amazonians (pp. 139-185). New York, NY: Academic Press.

Hill, K., Hawkes, K., Hurtado, A. M., \& Kaplan, A. (1984). Seasonal variation in the diet of Ache hunter-gatherers in eastern Paraguay. Human Ecology, 12(2), 101-135.

Hill, K., \& Hurtado, A. M. (1989). Hunter-gatherers of the new world. American Scientist, 77, 437-443.

Hill, K., \& Hurtado, A. M. (1996). Ache life history: The ecology and demography of a foraging people. New York: Aldine de Gruyter.

Hopwood, C. J., \& Donnellan, M. B. (2010). How should the internal structure of personality inventories be evaluated? Personality and Social Psychology Review, 14, 332-346.

Hurtado, A., Hawkes, K., Hill, K., \& Kaplan, H. (1985). Female subsistence strategies among the Ache of eastern Paraguay. Human Ecology, 13, 1-28.

Jonason, P. K., Li, N. P., Webster, G. D., \& Schmitt, D. P. (2009). The dark triad: Facilitating a short-term mating strategy in men. European Journal of Personality, 21(1), 5-18. 
Keller, M. C., \& Miller, G. (2006). Resolving the paradox of common, harmful, heritable mental disorders: which evolutionary genetic models work best? Behavioral and Brain Sciences, 29, 385-404.

Keller, M. C., Coventry, W. L., Heath, A. C. \& Martin, N. G. (2005). Widespread evidence for non-additive genetic variation in Cloninger's and Eysenck's personality dimensions using a twin plus sibling design. Behavioral Genetics, 35, 707-21.

Kendler, K. S., \& Karkowski-Shuman, L., (1997). Stressful life events and genetic liability to major depression: genetic control of exposure to the environment? Psychological Medicine, 27, 539-547.

Kruuk, L. E. (2004). Estimating genetic parameters in natural populations using the "animal model". Philosophical transactions of the Royal Society of London. Series B, Biological Sciences, 359(1446), 873-890.

Li, J. Z., Absher, D. M., Tang, H., Southwick, A. M., Castro, A. M., Ramachandran, S. et al. (2008). Worldwide human relationships inferred from genome-wide patterns of variation. Science, 319, 1100-1104.

Lukaszewski, A. W., \& Roney, J. R. (2011). The origins of extraversion: joint effects of facultative calibration and genetic polymorphism. Personality \& social psychology bulletin, 37(3), 409-421.

Lynch, M., \& Hill, W. G. (1986). Phenotypic evolution by neutral mutation. Evolution, 40(5), $915-935$.

Martin, N. G., Jardine, R., Andrews, G., and Heath, A. C. (1988). Anxiety disorders and 
neuroticism: Are there genetic factors specific to panic? Acta Psychiatrica Scandinavica, 77, 698-706.

McCrae, R. R., \& John, O. P. (1992). An introduction to the five-factor model and its applications. Journal of Personality, 60(2), 175-215.

Mealey, L. (1995). The sociobiology of sociopathy: An integrated evolutionary model. Behavioral and Brain Sciences, 18, 523-599.

Mendle, J., Paige Harden, K., Turkheimer, E., Van Hulle, C. A., D’Onofrio, B. M., BrooksGunn, J. et al. (2009). Associations between father absence and age of first sexual intercourse. Child Development, 80, 1463-1480.

Gilmour, A. R., Gogel, B. J., Cullis, B. R., \& Thompson, R. (2009). ASReml User Guide, version 3.0 VSN International.

Nettle, D. (2005). An evolutionary approach to the extraversion continuum. Evolution and Human Behavior, 26, 363-373.

Olson, J. M., Vernon, P. A., Harris, J. A., \& Jang, K. L. (2001). The heritability of attitudes: A study of twins. Journal of Personality and Social Psychology, 80, 845-860.

Ozer, D. J., \& Benet-Martinez, V. (2006). Personality and the prediction of consequential outcomes. Annual Review of Psychology, 57, 401-421.

Penke, L. (2010). Bridging the gap between modern evolutionary psychology and the study of individual differences. In D. M. Buss \& P. H. Hawley (Eds.), The evolution of personality and individual differences (pp. 243-280). New York, NY: Oxford University Press. 
Penke, L., Denissen, J. J. A., \& Miller, G. F. (2007). The evolutionary genetics of personality. European Journal of Personality, 21, 549-587.

Prokosch, M. D., Yeo, R. A., \& Miller, G. F. (2005). Intelligence tests with higher g-loadings show higher correlations with body symmetry: Evidence for a general fitness factor mediated by developmental stability. Intelligence, 33, 203-213.

Radcliffe-Brown, A. R. (1927). The regulation of marriage in Ambrym. The Journal of the Royal Anthropological Institute of Great Britain and Ireland, 57, 343-348.

Rodd, F. H., Reznick, D. N., \& Skolowski, M. B. (1997). Phenotypic plasticity in life history traits of guppies: Responses to social environment. Ecology, 78, 419-433.

Rowe, D. C. (2002). On genetic variation in menarche and age at first sexual intercourse: A critique of the Belsky-Draper hypothesis. Evolution and Human Behavior, 23, 365-372.

Smith B. R., Blumstein D. T. (2008). Fitness consequences of personality: a meta-analysis. Behavioral Ecology, 19, 448-455.

Symons, D. (1990). Adaptiveness and adaptation. Ethology and Sociobiology, 11, 427-444.

Tither, J.M., \& Ellis, B.J. (2008). Impact of fathers on daughters' age at menarche: A genetically- and environmentally-controlled sibling study. Developmental Psychology, 44, 1409-1420.

Trull, T. J., \& Sher, K. J. (1994). Relationship between the five-factor model of personality and Axis I disorders in a nonclinical sample. Journal of abnormal psychology, 103(2), 350360. 
van Os, J., \& Jones, P. B. (2001). Neuroticism as a risk factor for schizophrenia. Psychological Medicine, 31, 1129-1134.

Williams, G. C. (1975). Sex and evolution. Princeton, NJ: Princeton University Press. Williams, G. C. (1957). Pleiotropy, natural selection, and the evolution of senescence. Evolution, 11(4), 398-411.

Wilson, A. J., Reale, D., Clements, M. N., Morrissey, M. M., Postma, E., Walling, C. A., et al. (2010). An ecologist's guide to the animal model. The Journal of animal ecology, 79(1), 13-26.

Wilson, D. S. (1994). Adaptive genetic variation and human evolutionary psychology. Ethology and Sociobiology, 15, 219-235.

Yeo, R. A., Gangestad, S. W., Edgar, C. \& Thoma, R. J. (1999). The evolutionary-genetic underpinnings of schizophrenia: The developmental instability model. Schizophrenia Research, 39, 197-206.

Yeo, R. A., Gangestad, S. W., Gasparovic, C., Liu, J., Calhoun, V. D., Thoma, R. J., et al. (2011). Rare copy number deletions predict individual variation in human brain metabolite concentrations in individuals with alcohol use disorders. Biological psychiatry, 70(6), 537-544.

Zietsch, B. P., Verweij, K. J., Heath, A. C., \& Martin, N. G. (2011). Variation in human mate choice: simultaneously investigating heritability, parental influence, sexual imprinting, and assortative mating. The American Naturalist, 177(5), 605-616. 
VITA

Drew H. Bailey was born in Austin, Texas, and grew up in Evanston, Illinois, where he attended Evanston Township High School. He completed his Bachelor of Arts degree in psychology, with a minor in linguistics, at the University of Texas at Austin in 2006. $\mathrm{He}$ then attended the University of Missouri, where he earned his Master's in 2009 and Ph.D. in 2012 under the advisement of Professor David Geary. In the fall of 2012, Drew will begin a postdoctoral position with Robert Siegler at Carnegie Mellon University. 